\title{
WHY THE GLEAN AIR ACT WORKS BADLY
}

\author{
William F. Pedersen, JR. $\dagger$
}

As the Glean Air Act, ${ }^{1}$ perhaps the nation's most important, and certainly its most controversial, environmental regulatory statute, approaches its scheduled reauthorization by the 97 th Congress, ${ }^{2}$ major amendments seem increasingly likely. Economic concerns, a general anti-regulatory mood, and, above all, the election in 1980 of a more conservative President and Congress all suggest that result. In addition, many supporters of strong environmental protection would agree that the statute's current structure is too cumbersome, and is poorly suited to address several of the emerging issues in air pollution control. ${ }^{3}$

† Deputy General Counsel, Environmental Protection Agency. B.A. 1965, LL.B. 1968, Harvard University. The views expressed in this article are those of the author only and not necessarily those of the Environmental Protection Agency or of any other employee of the Environmental Protection Agency.

1 The Clean Air Act in its original form was enacted as the Clean Air Act of 1963, Pub. L. No. 88-206, 77 Stat. 392 (1963). It has since been amended several times: Pub. L. No. 89-272, 79 Stat. 992 (1965); Pub. L. No. 89-675, 80 Stat. 954 (1966); Pub. L. No. 90-148, 80 Stat. 485 (1967); Pub. L. No. 91-137, 83 Stat. 283 (1969); Pub. L. No. 91-604, 84 Stat. 1676 (1970); Pub. L. No. 92-157, 85 Stat. 464 (1971); Pub. L. No. 93-15, 87 Stat. II (1973); Pub. L. No. 93-319, 88 Stat. 248, 261, 265 (1974); Pub. L. No. 95-95, 91 Stat. 685 (1977), and Pub. L. No. 95-190, 91 Stat. 1399 (1977). By far the most important of these enactments are the Clean Air Amendments of 1970, Pub. L. No. 91-604, 84 Stat. 1676 (1970), which gave the statute its present form, and the Clean Air Act Amendments of 1977, Pub. L. No. 95-95, 91 Stat. 685 (1977), which extensively altered the details of the structure that the 1970 amendments established. The Clean Air Act as amended is codified at 42 U.S.C. $\$ \$ 7401-7642$ (Supps. II 1978 \& III 1979).

2 The statute's authorization for appropriations expires in October 1981 and must be legislatively extended. 42 U.S.C. $\$ 7626$ (Supp. III 1979). The difficult nature of the issues and the relatively slow startup in legislative activity to be expected from the change in the leadership of both the executive branch and the Senate as a result of the 1980 election, however, will probably delay final action until at least the end of the 97th Congress. The authorization for appropriations in the 1970 version of the statute expired in mid-1973, Pub. L. No. 91-604, 84 Stat. 1705, 1709, but the statute itself was not fully rewritten until 1977.

3 See, e.g., Ackerman \& Hassler, Beyond the New Deal: Coal and the Clean Air Act, 89 YArE L.J. 1466, 1566 (1980) ("The [Clean Air] Act discarded the idea that policymaling should be insulated from direct congressional intervention. But instead of providing a solution responsive to the evolving will of a national majority, congressional intervention mixed clean air symbols and dirty coal selfinterest in a way that invites cynicism about democratic self-government."); Currie, Relaxation of Implementation Plans Under the 1977 Clean Air Act Amendments, 78 Mick. L. Rev. 155, 201 (1979) ("The bewildering menagerie of [variance] provisions in the 1977 Act promises to be a rich source of expensive and time-consuming litigation. . . [T]hey provide only temporary symptomatic relief for the continuing malady of statutory inflexibility. . . . It is tempting to say that Congress has failed to learn from its mistakes."); Currie, Nondegradation and Visibility Under the Clean Air Act, 68 CAxrF. L. REv. 48, 82 (1980) ("[T]he 
This article describes some of the statute's more serious defects, and offers one possible cure for them. It begins by identifying three basic objectives for the Clean Air Act (the Act). First, the regulatory system created by the statute should readily incorporate new knowledge as it arises. Our understanding of pollution is too limited and too rapidly evolving to allow the statute to be built directly on today's hypotheses. Second, this system should control pollution in the most economically efficient manner. Finally, the mechanical, legal, and procedural workings of the control scheme should strive towards simplicity and consistency.

Each of these three goals places its own distinct demands on the regulatory framework required by the statute. All three demands, however, raise the central question of how to handle regulatory change. First, and most fundamentally, new knowledge regarding the causes and effects of pollution, or the cost and availability of controls, may suggest amendments to regulatory requirements. Second, regulated sources or pollution control agencies may seek these changes to meet existing requirements in a more efficient way. Finally, frequent minor and mechanical revisions will be necessary to the smooth functioning of the air pollution control effort, as they are to the operation of any complicated regulatory structure.

At present, the Act fails to deal acceptably with any of these issues. Under it, new scientific and technical knowledge always can-and frequently must-result in immediate changes in the corresponding regulatory requirements. The new requirements must then take effect within tight and somewhat arbitrary deadlines. The result is a control effort notably lacking in certainty or predictability.

One might think that a statute that demands such constant changes would at least avoid procedural obstacles to change. In fact, however, affirmative action at two levels of government-one state, one federal-is generally required to amend rules under the Act. This "double-key" requirement has offered few real benefits to offset its obvious procedural burdens.

These two characteristics of the present system combine to work against the attainment of any of the three goals suggested above. The unscheduled and unpredictable character of the regulatory changes that new knowledge can require has fostered a tendency to resist new knowledge. At the same time, the lengthy double-key approval process hampers both changes that are designed to meet

complex implementing provisions [for the Clean Air Act's 'prevention of significant deterioration' requirements] present both serious difficulties of interpretation and questionable policy choices."). 
present requirements in a more efficient way and housekeeping or mechanical changes.

This article argues that all these defects could be alleviated by statutory amendments that would shift the regulatory scheme toward greater reliance on fixed-term, source-specific, state-issued permits to regulate pollution sources. Changes to these permits resulting from new knowledge or new policy choices would generally be made only when they expired and were reissued. That would give such changes predictability and would thus make them easier to accept. This article also suggests that changes to meet existing requirements more efficiently, and housekeeping changes, should, by contrast, be freely available. In addition, all types of changes should be made procedurally easier by dropping the double-key requirement of affirmative approval by the Environmental Protection Agency (EPA or Agency). Instead, state-issued permits should take effect automatically unless the EPA objects to them within a specified, brief period.

\section{Goals for the Clean Air Act}

The Glean Air Act provides separate regulatory frameworks for different types of pollution "sources." Title I of the Act deals principally with controls on "stationary sources" of air pollution, such as factories and power plants, while title II focuses on "mobile sources," such as motor vehicles and aircraft." Title I imposes a complex and variable set of requirements on stationary sources. These requirements are largely contained in state implementation plans (SIPs), which are comprehensive pollution control programs

442 U.S.C. $\$ \$ 7521-7574$ (Supp. III 1979). This article does not discuss title II provisions. In brief summary, they authorize the EPA to impose emission limits on "motor vehicles" (trucks, busses, automobiles, and motorcycles) generally, id. $\$ 7521$ (a) (1), and on aircraft, id. $\$ 7571$. In many cases, particularly where automobiles are concerned, the title prescribes in elaborate detail either the level of the standards or the factors to be considered in setting them, and the procedures both for establishing these standards and for granting some temporary relief from their provisions. See, e.g., id. $\$ \$ 7521$ (a)(3), (a) (5), (b).

Title II also prescribes measures to ensure that vehicles actually meet these standards, such as testing and "certification" of prototypes before mass production begins, $i d$. $\$ 7525(\mathrm{a})$, testing of production vehicles just off the assembly line, id. $\$ 7525(\mathrm{~b})$, and testing of cars in actual use, $i d$. $\$ \$ 7541(\mathrm{~b}),(\mathrm{c})$. The manufacturer must warrant in several ways the ability of each in-use vehicle to meet the standard, and in particular must warrant that it will pass an in-use test if it has been "properly maintained and used," $i d$. $\$ \$ 7541$ (a), (b).

Title II also allows the EPA to control "additives" to motor fuel (for example, lead in gasoline), to eliminate both those that might damage a vehicle's emission control system, id. $\$ 7545$ (c)(1)(B), and those that might harm the public health directly, id. $\$ 7545(\mathrm{c})(1)(\mathrm{A})$. For a more detailed description of title II, see Currie, The Mobile-Source Provisions of the Clean Air Act, 46 U. CHr. L. REv. 811 (1979). 
established by each state subject to EPA approval. In addition, state-issued permits and national control standards supplement the SIP requirements of title $I$.

This article focuses on some procedural shortcomings of title $I$, and on a possible cure for these defects. Any analysis of procedure, however, requires some appreciation of the substantive nature of the field involved, and of the policy problems that arise there-problems that the statutory procedures should help to deal with or to answer. Although any short discussion of these issues must inevitably be somewhat personal, I believe three major goals for the Act have by now won general acceptance.

\section{A. Developing New Knowledge}

Regulatory agencies were originally created largely to accumulate expert knowledge in a field, update that knowledge, and apply it in a flexible manner to reach specified goals. ${ }^{5}$ Although this model of the agency has been criticized for treating questions that involve policy or political judgments as purely technical problems, ${ }^{\theta}$ an agency that abandons the model entirely is unlikely to reach rational results. This is particularly true in the environmental field, where problems are intricate and knowledge is incomplete and evolving. In this area at least, though it may not be possible to say that an answer is "right" on strictly technical grounds, because policy considerations must also be consulted, it is certainly possible to be wrong for strictly technical reasons. Case studies in environmental regulation have shown how often bad decisions are linked to a lack of knowledge. ${ }^{7}$

5 See Ackerman \& Hassler, supra note 3, at 1471 n.10 (citing J. FrEEDMaN, Crisis and Legrtmacy 32-33, 44-46, 59-60 (1978)); Stewart, The Reformation of American Administrative Law, 88 HaRv. L. Rev. 1667, 1676-81 (1975). Cf. J. Landis, The Administrative Process 23-24, 68-70 (1938).

6 Stewart, supra note 5, at 1682-88, 1702, 1712-15.

7 See, e.g., Ackerman \& Hassler, supra note 3, at 1483, 1517, 1522, 1523-24, $1526-32,1534-35,1554-55$ (decision on sulfur standards for coal-fired power plants made with imperfect knowledge of the effects of emitted sulfur compounds on health, visibility range, or acid rain; of the dispersion and transformation of sulfur compounds in the atmosphere; of reliability of different types of emission-reducing "scrubbers"; of the merits and drawbacks of "coal washing" as an alternative to "scrubbing" and of the variation in energy and sulfur content of various coal supplies). See also B. Ackgriman, S. Rose-Ackerman, J. Sawyer \& D. Henderson, THE UNCERTAIN SEARch FOR ENVIRONMENTAL QuALITY (1974) (decisions on effluent standards for the Delaware River made with imperfect knowledge of how oxygen-demanding wastes naturally disperse and are neutralized; of the possible adverse effects on the river of reducing the level of these wastes in the absence of other clean-up measures, and of the favorable impact (if any) of such a step on the fish in the river) [hereinafter cited as B. AckERMaAN]. 
Pollution control requirements, generally speaking, stem either from "ambient" calculations or from a "technology-based" standard. Under a ambient approach, the regulatory agency sets a desired level of air or water purity, and then computes and imposes the pollution reductions it estimates are necessary to achieve that goal. Under a technology-based system, the agency simply requires the "best" methods of pollution control without detailed assessments of ambient effects. ${ }^{8}$

A technology-based approach, by taking the focus off the fundamental question-the proper level of air or water purity-allows both regulators and the regulated to design a control system without seriously considering the goals it should achieve. Accordingly, as case studies have amply demonstrated, a purely technology-based approach will control some pollution sources too much and others too little, entirely overlook major contributors to the problem, or control the wrong pollutants. ${ }^{9}$

Title I of the Clean Air Act, to its great credit, is designed largely around ambient considerations. ${ }^{10}$ Such an approach, however, though free from fundamental conceptual flaws, has serious problems of implementation. In particular, the treatment of new knowledge takes on added significance where ambient-based controls are involved. An ambient scheme forces the development of new knowledge about pollution by making that knowledge relevant to the very practical task of setting emission standards. This demand for new knowledge, however, constantly calls the foundations of the approach that demands it into question. Developments under the Act illustrate this in several ways.

Most obviously, our understanding of what constitutes an ambient "problem" can change. For example, one air quality standard-for ozone-has been relaxed by fifty percent since it was set ten years ago..11

$8 \mathrm{~J}$. Bonine \& T. McGarity, The Law of Environment and Pollution, at I-53, 96-106, II-1-155, III-I-156 (1980) (unpublished teaching materials used at the University of Texas and University of Oregon Law Schools).

${ }^{9}$ See Ackerman \& Hassler, supra note 3, at 1515-36, 1543-45 (EPA "new source performance standards" for coal-fired power plants lack any consistent environmental purpose, control new sources too much and old sources too little, rely on the most expensive and least reliable of the major control alternatives, and focus on sulfur oxides rather than "sulfates," which are more important); B. ACKERMAN, supra note 7 (Delaware River Basin Water Pollution Control program controls industrial and municipal dischargers too much, leaves overflow from combined storm sewers completely uncontrolled, and emphasizes simple biological wastes rather than toxic metals and chemicals).

10 See notes 36-56 infra \& accompanying text.

11 Compare 36 Fed. Reg. 8,186 (1976) (0.08 ppm) with 44 Fed. Reg. 8,202, 8,220 (1979) (codified at 40 G.F.R. $\$ 50.9$ (1980)) (0.12 ppm). 
More dramatically, two other standards-those for sulfur oxides and "particulates"-face review amid widespread, but ill-documented, concerns that they may fundamentally mistake the problems at issue. Sulfur oxides are now regulated to control concentrations in gaseous form relatively close to emission sources. Yet more damage may be caused when those oxides-as well as nitrogen oxides-are transformed over time in the atmosphere into "sulfates," "nitrates," or "acid rain" that fall to earth hundreds or even thousands of miles from their place of origin. ${ }^{22}$ Similarly, the current particulates standard applies to all pieces of airborne dust less than approximately fifty micrometers in diameter, even though many qualified people believe that health risks may generally result only from the smaller particles in this range. ${ }^{13}$ These questions will not be rapidly resolved. Their existence shows, however, that for years to come the statute will have to reckon with incompletely answered questions at its very foundations. If those questions receive future answers different from the ones accepted today, significant restructuring of the pollution control effort may result.

Even on a day-to-day level, without considering fundamental changes in air quality standards, the ambient approach predictably generates knowledge that challenges the foundations of the regulatory system. A description of the process by which actual emissions controls are set will demonstrate this point. The task of setting control requirements in a region so that applicable ambient standards will be attained proceeds in four stages. ${ }^{14}$

12 For discussion of "sulfates" and "nitrates," see H. LANDSBERG, et al., ENERGY: The Next Twenty YeARs 336-39, 342-43, 363-64 (1979); NATIONAL Commission on AIR Quarity, To Breathe Clean AIR 2.1-70-72, 3.4-55, 3.9-6, 9, 11-15, 17-22 (1980) [hereinafter cited as Nat'L Commission]. See also Ackerman \& Hassler, supra note 3 , at 1515-22.

In addition, new data suggest that ozone may be atmospherically transported, thereby causing potential air quality problems, over much greater distances than had previously been assumed. See NAr'L Commission, supra, at 2.1-27, 70, $3.4-55,3.9-5,8-10$.

13 On this point, see NAT'L Commussion, supra note 12, at $2.1-5,3.1-10-11$, 3.4-59; II CouncIL ON ENVT'L QUALITY ANN. REP. 173 (1980).

14 This approach is summarized in various EPA regulations and other publications. See, e.g., 40 C.F.R. $\$ \$ 51.10(\mathrm{e}), 51.12,51.13(\mathrm{~d})-.13(\mathrm{~g}), 51.14(\mathrm{c})-.14(\mathrm{~g})$, Part 51 Appendix A (1980). See also U.S.E.P.A., Office of AIr Quality Planning and Standards, Gumelines on Am Quality Models, No. 1.2-080 (1978) [hereinafter cited as Moderung Gumer.nNes]. See also Ohio Envt'l Council v. EPA, 593 F.2d 24, 30 n.4 (6th Cir. 1979); Cleveland Elec. Illuminating Co. v. EPA, 572 F.2d 1150, 1160-63 (6th Cir. 1978); Texas v. EPA, 499 F.2d 289, 294, 297312 (5th Cir. 1974). For outlines of the process, both for areas that have not attained the established standards and for those in which the standards are met and the prevention of significant deterioration is the goal, see NAT'L CoMmrssron, supra note 12 , at $3.2-5,15-22,3.5-28-32$. 
First, actual measurements of air pollution levels throughout the region identify where, and to what extent, existing standards are exceeded.

Second, the regulatory agency must compile an "inventory" of the emission sources in the area. Because, at least for some pollutants, a source's impact on air quality as currently measured can vary with its location, stack height, exhaust gas velocity, or the characteristics of its emissions, information on each of these facts should ideally be included.

Third, the agency must apply a mathematical model to predict how the emissions from the particular sources on the inventory give rise to the current pollution levels. Although some models are quite simple-consisting of little more than an assumption that an $\mathrm{X} \%$ reduction in emissions will lead to an $\mathrm{X} \%$ reduction in ambient pollution levels-in general the trend is towards increasing complexity. Local air quality readings, emissions data from the inventory, and detailed meteorological data for the region are combined with experimental measurements of the behavior of gases in terrain similar to that of the area being modelled to mathematically predict, under various control choices, ambient pollution levels in future weather conditions.

Finally, the agency must actually set control requirements for the sources in the inventory. In some cases the model will require a certain minimum level of control for a source. In others, the agency will have to choose among several satisfactory patterns of control.

Not all these steps need necessarily be followed in every case. In some, the model will be so simple that its application is only a formality. In others, the model and the inventory will be used to predict air quality directly, without reference to ambient readings. ${ }^{15}$ The general trend, however, is toward increased reliance on each step of this process.

Each of these four steps is subject to continual change. New air quality data can suggest that the ambient problems are better, worse, or different from what previous data had suggested. Sources can alter their emissions characteristics, or close down and be removed from the inventory. New sources may open, and sources

15 So, in Mision Indus., Inc. v. EPA, 547 F.2d 123, 128-29 (1st Cir. 1976), the court upheld the EPA's use of a model with an admitted wide range of error to determine emission requirements for Puerto Rico, even though its predictions had never been checked against actual air quality readings. The court accepted the Agency's argument that the available air quality data was incomplete, and that use of an uncorrected model was scientifically preferable to use of a model checked against inadequate data. 
that were overlooked when the inventory was compiled may be discovered. New meteorological data may change the results that the model yields. Finally, the mathematical structure of the model itself may shift as knowledge advances.

None of these changes or potential changes in the knowledge needed to operate an ambient control scheme should be resisted taken by itself. The alternative to welcoming new knowledge is to be willfully ignorant. It is important, however, that a regulatory statute that is so subject to change be designed to absorb and implement changes in a practical, nondisruptive way. Frequently this will require scheduling changes in a predictable manner, rather than implementing them immediately.

Should existing knowledge suggest, however, even inconclusively, that present levels of pollution are unacceptably high, seeking further knowledge should perhaps be subordinated to taking quick action. ${ }^{16}$ That approach justifies the costs of hasty, disruptive, and inefficient action by pointing either to the great extent of current harm or the great risk of future harm. Controversy surrounds the extent and nature of the harm now resulting from air pollution, ${ }^{17}$ and the question whether it justifies extreme measures must, at least to some extent, remain a matter of judgment. Air pollution levels, however, have declined somewhat-though not dramaticallyover the past decade, ${ }^{18}$ and presently scheduled control measures are projected, in most cases, either to produce further improvements or to hold matters constant over the next ten years. ${ }^{19}$ Whatever

16 See Ackerman \& Hassler, supra note 3, at 1530.

17 See NAT'L Commssion, supra note 12, at 2.1-8, 4.1-5-10 (studies of costs avoided by air pollution control range from $\$ 4.6$ to $\$ 51.2$ billion annually). See also H. LANDSBERG, supra note 12, at 351, 365, 366-67.

18 See Nat'L Commssion, supra note 12, at 1.1, 3.4-1-2; 11 Councri on ENVT'L Qualixy ANN. REP. 146 (1980). Nitrogen oxides (up 17\%) are the only exception to an eight-year trend of decreasing national pollution emissions. Id. 170 .

19 Existing pollution levels for carbon monoxide, particulates, and ozone are projected to decrease unambiguously from current levels over the next decade, given current control programs. NAT'x Commissron, supra note 12 , at $2.1-23-25,3.4-$ 27-30, 60-61.

Atmospheric sulfur oxide concentrations above the present standards are likewise projected to become less frequent. Id. 2.1-23, 3.4-32, 61. Meanwhile, total national emissions of sulfur oxides (which may cause "acid rain") are projected to remain almost constant. Id. 2.1-73, 3.9-23. Sulfur oxide emissions in the western United States, however, will increase during this period. Id. 2.I-73.

The current air quality standard for nitrogen oxides is rarely exceeded now and violations are projected to decrease in the future. Id. $2.1-25-26,3.4-32-34$, 3.1-61. However, total national emissions of nitrogen oxides (which also may cause "acid rain") are projected to increase somewhat. Id. 2.1-73.

For a summary, see $i d$. at $2.1-87-88,4.2-9-10,35$ (assuming current control programs, "particulate, hydrocarbon, and carbon monoxide emissions may each decrease by approximately 30 percent or more by 1990." Sulfur dioxide emission 
one thinks of the extent and regulatory significance of air pollution's current costs, these factors suggest that future costs will probably not be greater. This in turn makes an argument for haste based solely on future effects harder to justify. ${ }^{20}$

\section{B. Economic Efficiency}

A second fundamental objective that the Act should strive to attain is the development of an economically efficient system of pollution control. Economists have long pointed out the inefficiency of regulations that require all pollution sources to reduce their emissions equally, and have argued that the same reductions could be achieved at less cost by mechanisms that rely on individual selfinterest to shift the control burden to those who can bear it most cheaply. ${ }^{21}$ The argument starts from the observation that the cost of a given control level frequently will vary among plants within an area. Accordingly, a regulation that forces all plants in a category to "emit no more than $\mathrm{x}$ " often will be inefficient, since the same results could likely be reached by allowing plant $A$ (where control costs are high) to emit a little more, while requiring plant $B$ (where control costs are low) to emit a little less. Although total emissions will be unchanged, the cost of control will decrease, because high-cost reductions at plant $A$ will be replaced by low-cost reductions at plant $B$.

The literature describes two different ways of achieving this result. First, emissions could be taxed at a uniform rate. Polluters would control their emissions down to, but not beyond, the point at which paying the tax became cheaper than further controls. Those for whom control was cheap would therefore end up controlling more (though not necessarily spending more) than those for whom control was expensive, and the overall cost of the reduction would be minimized. ${ }^{22}$

levels will essentially remain the same and nitrogen oxides emission levels will remain the same or slightly increase).

20 For a similar argument in the context of measures to reduce sulfur oxides emissions, see Ackerman \& Hassler, supra note 3, at 1529-35.

21 A. Kneese \& C. Scrultze, Pollution, Prices, and Public Poltcy 1-2, 81-84 (1975); Introduction to ECONOMICS OF THE ENVRRONMENT XXxvi-xxxviii (R. Dorfman \& N. Dorfman eds. 1972); Ruff, The Economic Common Sense of Pollution, in id. 11.

22 A. KNEESE \& C. SGHULTZE, supra note 21, at 2, 87-96; Introduction, supra note 21, at xxxviii-xl; Ruff, supra note 21 , at 13-19. 
A "pollution tax" would not set any direct control requirements for pollution sources. Even if a pollution tax is rejected, however, and requirements are set directly, economic efficiency could be improved by a scheme that allowed sources to trade reduction obligations among themselves. In other words, plant $A$ would be allowed to increase its emissions if plant $B$ agreed to reduce its emissions by the same amount, leaving total emissions unchanged. If plant $A$ had higher control costs than plant $B$, both could profit in such a system if plant $A$ paid plant $B$ for its extra control effort. As long as the payment from $A$ to $B$ was less than $A$ 's control cost, but more than $B$ 's, both parties would be better off, total control costs would be reduced, and total emissions would be unchanged.

For various reasons, the "pollution rights" approach seems more attractive for immediate use than the taxation approach. ${ }^{23}$ It also appears to fit the Clean Air Act better than the other EPA statutes. ${ }^{24}$ There, on a bureaucratic time scale, progress has been considerable.

23 See B. Ackerman, supta note 7, at 260-81.

24 Such approaches have most often been urged for the control of air and water pollution. Because of the way the statutes are drafted, however, a "pollution rights" approach fits the Clean Air Act better than the EPA's water pollution control statute, the Clean Water Act. The Clean Air Act primarily aims to reduce overall emissions in an area enough to meet air quality standards. To the extent different patterns of control will meet this basic goal, the statute raises no obstacle to any approach that would allow sources to reallocate control duties through the market.

The Clean Water Act emphasizes to a much greater extent the duty of each "point source" of water pollution to meet certain basic technical standards. See note 115 infra. Any reallocation effort is therefore subject to the charge that it allows sources that will discharge more pollution than originally planned to evade their basic duty to meet the minimum technology-based level of control. In fact, largely due to this argument, the EPA's efforts to adopt a "bubble" approach to water pollution control have remained static for several years, while the "bubble" approach in air pollution has moved steadily forward. Compare [Current Developments] 9 ENvir. Rep. (BNA) 1815, 1901 (Feb. 2, 1979) with 46 Fed. Reg. 20,554 (1981).

The solid waste disposal regulatory area is simply too new for any of the necessary thinking and writing to have been done. The EPA's initial regulatory effort will concentrate on such basic questions as how to classify a waste as hazardous and how to set standards for safe disposal. Even there, the answers will be rough-hewn at best for quite a few years. Only after these basic questions about the degree of danger associated with wastes, and how it can be reduced, have been answered in more detail will it be possible to devise market-based methods of attaining statutory goals.

Finally, the Agency's two major "chemical control" statutes, the Toxic Substances Control Act, 15 U.S.C. $\$ \$ 2601-2629$ (1976), and the Federal Insecticide, Fungicide, and Rodenticide Act, 7 U.S.C. $\$ 135-136$ (1976), focus on the control of chemicals that may be long-lived, mobile in the environment, and highly toxic. Economic control approaches are generally considered unsuited for dealing with the class of problems posed by these substances-most often the question is rather whether the social costs of a given use outweigh the benefits, and whether use should be allowed at all. 
Through its "bubble" ${ }^{25}$ and "offset" ${ }^{26}$ policies, the EPA now allows one polluter, in certain circumstances, to increase its emissions if it can induce another polluter to reduce emissions by a corresponding amount. Alternatively, a polluter with low marginal control costs can reduce pollution by more than the law requires, and then save or "bank" the rest for future sale or use. ${ }^{27}$ These are new approaches, and presently lack major importance in the daily workings of the statute. Congress, however, extended the EPA's first efforts in the field when it revised the Act in 1977,28 and bolder steps are likely in the current political climate.

\section{Procedural Simplicity and Consistency}

Simplicity and consistency at the drafting level are basic tests for any statute. For title I of the Clean Air Act, however, these qualities derive a broader meaning from two particular aspects of the control scheme.

First, the Act does not exclusively call on either the federal government or the various state governments to achieve its ends. Instead, it yokes the two in an uneasy partnership in pursuit of a common goal. That, in turn, makes it all the more important that the decision-making procedures mandated by the Act be free from needless complexity.

Second, a fundamental purpose underlying the creation of the EPA was to provide a coordinated approach to pollution wherever it occurred. The ultimate goal was to base regulatory decisions on what best served a wide variety of environmental goals, and not simply on what would clean up the air or the water taken by themselves. The present statute contains little recognition that the EPA

25 See 44 Fed. Reg. 71,780 (1979).

26 See 41 Fed. Reg. 55,524 (1976), revised, 44 Fed. Reg. 3,274 (1979), revised again, 45 Fed. Reg. 31,31I (1980) (codified at 40 C.F.R. $\$ 51$ Appendix S (1980)). The EPA has recently further amended these regulations. See 45 Fed. Reg. 52,676, 52,741-43 (1980).

27 The EPA explicitly prohibited "banking" in its original offset ruling, see 41 Fed. Reg. 55,524, 55,526 (1976), and then reversed itself two years later, see 44 Fed. Reg. 3,274, 3,280, 3,285 (1979) (codified at 40 C.F.R. $\$ 51$ Appendix S (1980)). The Agency is developing a proposed policy statement to set the terms and conditions under which emission reductions may be "banked" and used to meet future air pollution control requirements.

On the subject of offset-banking, see generally Comment, Emission-Offset Banking: Accommodating Industrial Growth With Air-Quality Standards, $128 \mathrm{U}$. PA. L. REv. 937 (1980).

28 Congress explicitly adopted the EPA's "offset" approach as the governing rule in nonattainment areas, see text accompanying notes 49 \& 50 infra, pending the development of nonattainment SIPs. See $\$ 129$ (a)(1) of Pub. L. No. 95-95, 91 Stat. 745 (1977). States would thereafter have discretion whether or not to adopt this approach in their SIPs. 
administers laws to control water pollution, ${ }^{29}$ solid waste pollution, ${ }^{30}$ ocean dumping of pollutants, ${ }^{31}$ and the safety of underground drinking water sources, ${ }^{32}$ or that each of these other types of pollution can affect or be affected by measures to control air pollution. ${ }^{33}$ This problem, long obvious in the abstract, has assumed life in the practical world through the EPA's promulgation of regulations to control wastes disposed of on land. ${ }^{34}$ Much land disposal has occurred because disposal into air or water was tightly controlled, while land disposal was not. Now that the EPA will also restrict land disposal, the question of what to do with these wastes becomes more acute. ${ }^{35}$ This question cannot be answered without examining the relative merits of various disposal alternatives, which are often governed by different EPA statutes.

29 The Federal Water Pollution Control Act (commonly referred to as the Clean Water Act), 33 U.S.C. $\$ \$ 1251-1376$ (1976 \& Supp. III 1979).

30 The Solid Waste Disposal Act, 42 U.S.C. $\$ \$ 6901-6987$ (1976), as amended by Pub. L. No. 96-463, 94 Stat. 2055 (1980). This statute is generally called "RCRA," from the Resource Conservation and Recovery Act of 1976, Pub. L. No. 94-580, 90 Stat. 2795, which amended the Solid Waste Disposal Act into its present form.

31 The Marine Protection, Research, and Sanctuaries Act of 1972 (commonly referred to as the Ocean Dumping Act), 33 U.S.C. $\$ \$ 1401-1444$ (1976).

32 The Safe Drinking Water Act, which is set forth as Title XIV of the Public Health Service Act, requires the EPA to establish a program to protect these sources. 42 U.S.C. $\$ \$ 300 f-j(1976)$.

33 According to the 1979 Annual Report of the Council on Environmental Quality, air pollution is a major source of pollution of the Great Lakes by heavy metals, lead in particular. 10 Councri on ENvT't QuAtuTr AnN. REP. 98-99 (1979). More generally, fallout from air pollution onto pavement can be a major cause of "non-point source" water pollution when it is washed off by rain. Id. 86, 99-100. Some types of "scrubbers" to control emissions of sulfur oxides can cause a solid waste problem by generating a "sludge" of the limestone slurry used to remove the sulfur.

These links between air pollution and pollution of other types are not nearly as strong as the four-way link between discharges into surface waters, the ocean, or underground drinking water, and storage of the same material on land. See note 35 infra. They are important enough, however, to be a point in favor of a regulatory scheme that is capable of considering them.

3440 C.F.R. $\$ \$ 260-65$ (1980). These regulations, which as originally published in the Federal Register occupied 192 pages, designate several hundred chemicals as "hazardous waste." Persons who generate or transport such wastes must keep records of what is done with them, and the wastes may be disposed of only at sites that have received a permit to do so. For a detailed description of these regulations, see Rogers, RCRA Regs.: Enforcing EPA's Most Pervasive Statute, Legal Times of Washington, May 12, 1980, at 23, col. 1 .

35 RCRA . . may be the most important environmental law, not just because it creates a regulatory program for a broad range of activities that until now were virtually untouched by government, but also because RCRA may "back out" tough questions under a variety of other federal pollution control laws-questions that we have not come to grips with 


\section{Stationary Sources Under the Glean Air AGT}

The following sections examine the present treatment of stationary sources under title $I$. After first providing a brief overview of that title, the discussion moves on to examine how the existing regulatory structure conflicts with the objectives discussed above: the incorporation of new knowledge, the achievement of efficient regulation, and the maintenance of procedural simplicity and consistency.

because ultimate disposal of pollutants never really had to be considered before.

Is it less dangerous to remove persistent and toxic substances from the air and water, where they may be dispersed in low concentrations, and place them in the ground in very high concentrations? Even if it may be safer to collect these pollutants and bring them somewhere, is it worth the cost (including the energy costs)? Where should these pollutants-some of which last and are toxic for several generations (or are elements and are around forever)-be placed and who should be involved in deciding where they should go?

Heavy metals such as chrome and cadmium are discharged into city sewers by a number of manufacturing concerns. Under the Clean Water Act, there are standards based on technology, rather than calculated effects on the receiving water, that require installation of pollution control equipment at each discharging facility to collect most of these metals. The owner of the plant then must find a way to dispose of the metals.

The new RCRA regulations-which are based on potential effects on the environment-rather than on availability of disposal technologymay make it difficult, and certainly more costly, for this businessman to find a satisfactory disposal option.

He may consider incineration, but this activity may run afoul of the Clean Air Act regulations, which have been ... largely designed to protect the air around us-and not to protect the air around us only to the extent it doesn't cause greater damage to the groundwaters under us. The ocean dumping laws were drafted with little consideration of the relative dangers of on-land disposal; Congress (and EPA's regulations carry out this theme) wanted the oceans free of possibly damaging pollution.

Role of Cost Analysis

Under each disposal option, the costs vary, and under each law, the ability of EPA to consider costs also varies. Under the Clean Water Act's pretreatment standards, costs and economic impact must be considered. Under the Clean Air Act it depends on what section is relied on. . . Under the ocean dumping law, costs of alternatives play a minor role. Under RCRA, it is unclear what role economics has.

So, as the molecules of chrome and cadmium compounds pass from factory to sewer to river, to landfill, or to incinerator or ocean-going barge, they pass from one regulatory authority to another, from one law to another. Different congressional committees have drafted detailed laws that respond to different environmental concerns, that respond to interest groups that are surprisingly tied to consideration of issues in the context of a single medium.

Finding and executing overall solutions to the problems of disposal of toxic and persistent substances and molding amendments to the older environmental laws to allow this to take place, will be the environmental challenge for Congress in the 1980s.

Rogers, supra note 34, at 31, col. 2. 


\section{A. An Overview of Title I}

Title I of the Act employs a variety of approaches in regulating stationary sources. It mingles a number of technology-based requirements with its predominantly ambient approach. It also utilizes two different procedural vehicles-broad state-wide regulatory plans and source-specific permits-to articulate its substantive requirements. Finally, the Act contains a number of different methods for making its programs work across the federal-state divide. The complexities, both avoidable and unavoidable, that this diversity of approaches and procedures leads to are described below.

\section{What SIPS Are Based On}

The major theme of title I of the Act is the regulation of stationary sources through state implementation plans (SIPs) to achieve various air quality goals. ${ }^{36}$ Part $A$ of the title ${ }^{37}$ provides the basic framework. It commands the EPA to issue air quality criteria for any widespread air pollutant that "may reasonably be anticipated to endanger public health or welfare." 38 The EPA, on the basis of these criteria, must then set "national ambient air quality standards" (NAAQSs). These may be "primary" NAAQSs, which must be tight enough to "protect the public health," 39 or "secondary" NAAQSs, which must protect against harm to the public "welfare." "Welfare" effects include visibility impairment and damage to buildings and plant or animal life.40

36 The subtheme of title $I$ is installation of technology to control air pollution without direct reference to air quality benefits. To a great extent, the permits that every new source over a certain size must obtain impose these requirements. See text accompanying notes 96 \& 97 infra. In addition, since 1970 the statute has allowed the EPA to set "new source performance standards" that require categories of new sources to achieve the emission reductions "achievable through the application of the best system of continuous emission reduction which (taking into consideration the cost of achieving such emission reduction, and any nonair quality health and environmental impact and energy requirements) the Administrator determines has been adequately demonstrated for that category of sources." 42 U.S.C. $\$ 7411$ (a)(1)(C) (Supp. III 1979). Finally, the statute authorizes the Agency to establish emission standards for "hazardous air pollutants" that are applicable on a plant-by-plant basis without detailed calculations of the plant-specific ambient effects. Id. $\$ 7412$.

For further discussion of these provisions, see Currie, Direct Federal Regulation of Stationary Sources Under the Clean Air Act, 128 U. PA. L. Rev. 1389 (1980).

3742 U.S.C. $\$ \$ 7401-7428$ (Supp. III 1979).

$38 I d$. $\$ 7408$ (a) (I)(A).

39 Id. $\$ 7409$ (b). See generally Lead Indus. Ass'n v. EPA, Nos. 78-2201 and 78-2220 (D.C. Cir., filed Sept. 15, 1980), modifying Nos. 78-2201 and 78-2220 (D.C. Cir., filed June 27, 1980).

4042 U.S.C. $\$ 7409$ (b) (2) (Supp. III 1979). The statute requires secondary standards "to protect the public welfare from any known or anticipated adverse 
The Act further requires each state to submit an implementation plan detailing how it will attain the NAAQSs promulgated by the EPA.41 The plans are intended to be comprehensive bundles of strategies and commands, containing all the requirements necessary to attain the NAAQSs in that state. ${ }^{42}$ The Act established this procedure in 1970 , contemplating a reduction in air pollution to the level of primary NAAQSs by 1977 at the latest. ${ }^{43}$ In 197I, the EPA issued its most important air quality standards, ${ }^{44}$ and most

effects associated with the presence of such air pollutant in the ambient air." Id. A subsequent section then glosses this language as follows: "All language referring to effects on welfare includes, but is not limited to, effects on soils, water, crops, vegetation, manmade materials, animals, wildlife, weather, visibility, and climate, damage to and deterioration of property, and hazards to transportation, as well as effects on economic values and on personal comfort and well-being." Id. $\$ 7602(\mathrm{~h})$.

The present secondary standards, however, only take account of certain types of damage to vegetation, and are explicitly not designed to protect visibility in regions where the air is naturally very clear. See CommmTtee on INTERSTATE AND Foreign Commerce, Clean Arr Act Amendments of 1977, H.R. Rep. No. 294, 95th Cong., 1st Sess. 204-05, reprinted in [1977] U.S. Code Cong. \& AD. News $1077,1283-85$.

Literal compliance with the statute would have been very expensive, and quite probably unwise from a policy standpoint. Air quality standards, both primary and secondary, are meant to be nationally uniform. Yet, certain plant or animal species, or particularly clear ranges of natural visibility, exist only in limited portions of the country, and it would make little sense to impose everywhere a standard that produced benefits only in restricted areas. Probably for this reason, Congress has not really quarreled with the EPA's restrained approach to secondary standards, but has instead enacted additional programs to "prevent significant deterioration" of clean air, particularly in national park and monument areas, see notes 46-48 infra, and to preserve or restore exceptionally clear visibility where it naturally exists. 42 U.S.C. $\$ 7491$ (Supp. III 1979). Although this may be the best approach in the end, the fact that such programs would not be necessary under a literal reading of the "secondary standard" language introduces an inconsistency into the statute.

4142 U.S.C. $\$ 7410$ (a) (Supp. III 1979).

42 See id. $\$ \$ 7410(\mathrm{a})(2)(\mathrm{A}),(\mathrm{a})(2)(\mathrm{B}),(\mathrm{a})(2)(\mathrm{J})$. See also Train v. Natural Resources Defense Council, 421 U.S. 60, 65-67, 78-79, 80 (1975).

43 Section 110 of the Act, in both its present and its 1970 versions, requires states to submit SIPs pertaining to an NAAQS within nine months of its promulgation, allows the EPA four months to rule on them, and requires attainment of an NAAQS within three years of SIP approval. Id. $\$ \$ 7410$ (a)(I), (a)(2)(A)(i). Given the establishment of the main NAAQSs in 1971, see note 44 infra, this worked out to an "attainment date" of 1975. However, a further two-year extension was allowed, 42 U.S.C. $\$ 1710$ (e) (Supp. III 1979), and, because this extension was granted in virtually all cases for which the 1975 deadline proved problematic, 1977 became the effective deadline for meeting the primary NAAQSs.

44 See 36 Fed. Reg. 8,186 (1971) (ambient air quality standards for sulfur dioxide, particulates, carbon monoxide, hydrocarbons, photochemical oxidants (ozone), and nitrogen dioxide). The Agency has slightly revised the secondary standard for sulfur oxide, 38 Fed. Reg. 25,678 (1973), has relaxed both primary and secondary standards for photochemical oxidants by 50\%, and has eliminated the specific standard for hydrocarbons. See note 11 supra. The EPA has also established primary and secondary NAAQSs for lead. 43 Fed. Reg. 46,246 (1978). Current ambient air quality standards for sulfur dioxide, particulates, carbon monoxide, ozone, nitrogen dioxide, and lead are codified at 40 C.F.R. $\$ 50.4-12$ (1980). 
states submitted implementation plans by 1972. 1977's arrival, however, revealed widespread failure to reach the clean-up level of the primary standards.

In 1973, the Supreme Court affirmed a lower court opinion that interpreted a largely silent statute as requiring the EPA to prevent "significant deterioration" of the quality of air cleaner than required by the NAAQSs. ${ }^{45}$ As a result, the Agency was enjoined from approving SIPs that permitted such deterioration of air quality, even if they were adequate to prevent pollution levels from violating secondary standards. ${ }^{46}$ The EPA responded by issuing the regulations necessary to establish a "prevention of significant deterioration" (PSD) program. ${ }^{47}$ These regulations were then upheld by the United States Court of Appeals for the District of Columbia. ${ }^{48}$

The 1977 amendments to the Act explicitly adopted the PSD program. ${ }^{49}$ Congress required that each state, subject to EPA oversight, designate which areas within it were not attaining the NAAQSs, which areas were attaining them, and which areas could not be classified using the available information..$^{50}$ Once these "designations" were complete, each state was required to submit SIP revisions to the EPA. These revisions had to contain "nonattainment" provisions to cover areas that were not achieving the standards, and PSD provisions for the other two types of areas.

As in 1970, in 1977 Congress required that SIPs for "nonattainment" areas contain regulatory provisions that are sufficient to reduce air pollution to the level allowed by the applicable NAAQSs by a specific, tight deadline.51 The plans were also required to contain provisions mandating that each existing source install "rea-

45 Fri v. Sierra Club, 412 U.S. 541 (1973).

${ }^{46}$ See Sierra Club v. Ruckelshaus, 344 F. Supp. 253 (D.D.C.), aff'd mem., 4 E.R.C. 1815 (D.C. Cir. 1972), aff'd by an equally divided court sub nom., Fri v. Sierra Club, 412 U.S. 541 (1973) (requiring the EPA to establish a "prevention of significant deterioration" program).

4739 Fed. Reg. 42,510 (1974).

48 Sierra Club v. EPA, 540 F.2d 1114 (D.C. Cir. 1976) (upholding the EPA's original PSD regulations issued in response to the first Sierra Club case).

49 Clean Air Act Amendments of 1977, Pub. L. No. 95-95, $\$ 160,91$ Stat. 731 (current version at 42 U.S.C. $\$ 7470$ (Supp. III 1979)).

50 42 U.S.C. $\$ 7407$ (d) (Supp. III 1979). The EPA then must publish a list of these designations "with such modifications as [it] deems necessary." Id. $\$ 7407(\mathrm{~d})(2)$.

51 Primary NAAQSs for particulates and sulfur oxides must be attained by December 31, 1982, id. 7502(a)(1); for carbon monoxide and photochemical oxidants, the deadline can be as late as December 31, 1987. Id. $\$ 7502$ (a)(2). The Report of the National Commission on Air Quality indicates that these deadlines will not be met in all areas. NAT'L CoMmission, supra note 12, at 2.1-23-25, 3.4-21-34. 
sonably available control technology" 52 and that new sources install a higher level of control technology and meet certain other requirements. ${ }^{53}$ Plans for $\mathrm{PSD}$ areas were required to assure that air pollution would not increase above existing levels by more than statutorily specified amounts. ${ }^{54}$ The statute provides for doing this, in the first instance, by detailed regulation of all new sources over a certain size. The principal vehicles for such regulation are source-specific permits, which include technology-based control provisions. ${ }^{55}$ If that approach proves insufficient, the state must revise its SIP in order to correct any inadequacy. ${ }^{56}$ In addition, by cutting off federal funds and banning construction of major new sources of air pollution if the required plans are not timely submitted, the statute strongly encourages states to draw up nonattainment SIPs (but not PSD SIPs)..$^{57}$

5242 U.S.C. $\$ 7502(b)(3)$.

$53 \mathrm{Id}$. $\$ \S 7502(\mathrm{~b})(6), 7503$. See note 96 infra. In addition, SIPs for nonattainment areas must be adequate to show "reasonable further progress" toward the NAAQS as well as timely attainment of it, 42 U.S.C. $\$ \$ 7501$ (1), 7502(a), (b) (3) (Supp. III 1979), and must provide for a comprehensive inventory of the emissions sources in the area. Id. $\$ 7502(\mathrm{~b})(4)$. In certain cases they must also include a program for annual emissions testing of motor vehicles. Id. $\$ 7502$ (b) (11)(B). Nonattainment SIPs are also called "Part D" SIPs because the governing statutory provisions are set forth in Part D of title I. Id. $\$ \$ 7501-7508$.

54 The requirements for PSD SIPs are contained in Part $\mathrm{C}$ of title $\mathrm{I}$. Id. $\$ \$ 7470-7479$. These sections prescribe in detail the rules governing sulfur oxides and particulates. They direct that all PSD areas be divided into "Class I" areas, for which very little increase in pollution is permitted, "Class II," which may become somewhat more polluted, and "Class III," which in many cases may deteriorate down to the level of the NAAQS. Id. $\$ \$ 7472,7473(\mathrm{~b})$. The statute specifies precisely the maximum levels of sulfur dioxide or particulate increase (or "increments") allowed for all three types of areas. Id. $\$ 7473(\mathrm{~b})$. It also specifies the cases in which and the procedures by which an area may be "redesignated" from one category to another. Id. $\$ 7474$.

The regulations implementing these provisions have been the subject of massive legal controversy. The Agency promulgated its initial implementing regulations in June 1978. 43 Fed. Reg. 26,380 (1978), and they were promptly challenged in court. The United States Court of Appeals for the District of Columbia, in a preliminary opinion, upheld the EPA's choice of an effective date for the new requirements. Citizens to Save Spencer County v. EPA, 600 F.2d 844 (D.C. Cir. 1979). Its opinion on the merits, however, issued in both a preliminary version, Alabama Power Co. v. Costle, 606 F.2d 1068 (D.C. Cir. 1979), and a superseding final draft, 636 F.2d 323 (D.C. Cir. 1979), invalidated major portions of those requirements. The EPA has since promulgated its remand response, see 45 Fed. Reg. 52,676 (1980), and renewed litigation is under way.

The EPA was also directed, under less detailed standards, to establish PSD programs for nitrogen oxides, hydrocarbons, carbon monoxide, and photochemical oxidants. 42 U.S.C. $\$ 7476$ (Supp. III 1979). The implementing regulations have not yet been proposed.

55 See notes 96 \& 97 infra.

5640 C.F.R. $\$ 51.24(\mathrm{a})(3)$ (1980). See Alabama Power Co. v. Costle, 636 F.2d 323, 352 (D.C. Cir. 1979).

57 The statute in effect requires all SIPs to forbid the construction of any "major stationary source" in a nonattainment area after the date for submission of a 
SIPs, nonattainment designations, and PSD designations are all specific to one of the six pollutants for which the EPA has developed NAAQSs. Any source of air pollution that emits more than one such air pollutant, then, will be bound by separate SIPsseparate regulatory systems-for each of those pollutants. In addition, where a given region is nonattainment for some pollutants and PSD for others, the overlapping SIPs may be built on quite different statutory foundations. The statute contains no mechanism with which to coordinate the application of the different SIP requirements to a source, either with each other or with the separate requirements set through permits.

\section{Changes in the SIPs}

The Act allows the static regulatory framework just described to change over time in any of four major ways.

First, new data can show that, in the case of a nonattainment SIP, the SIP is inadequate to attain the NAAQS in question by the statutory deadline. In the case of a PSD SIP, new data can show that the SIP will not hold pollution increases below the allowable levels. If either situation occurs, the SIP must be tightened.58

Second, new data can show that the SIP could achieve its purpose with less strict controls, or with a different pattern of controls. Alternatively, even in the absence of new data, a state that made the policy decision to impose controls stricter than the federal minimum may change its mind. In these cases the state that submitted the SIP may elect to relax it.59

nonattainment SIP, unless that SIP has been submitted in satisfactory form. 42 U.S.C. $\$ 7410$ (a)(2)(I) (Supp. III 1979). See also id. $\$ 7506(a)$. In nonattainment areas where "transportation controls" to reduce motor vehicle emissions will be necessary, the statute provides for a cut-off of Department of Transportation and EPA grant funds in similar circumstances. Id. $\$ 7506(a)$. See also id. $\$ 7413(a)(5)$.

68 The EPA may approve a SIP only if it

provides for revision, after public hearings, ... whenever the Administrator finds on the basis of information available to him that the plan is substantially inadequate to achieve the national ambient air quality primary or secondary standard which it implements or to otherwise comply with any additional requirements established under the Clean Air Act Amendments of 1977.

Id. $\$ 7410(\mathrm{a})(2)(\mathrm{H})$.

59 "The Administrator shall approve any revision of an implementation plan applicable to an air quality control region if he determines that it meets [the basic requirements of the statute] and has been adopted by the State after reasonable notice and public hearings." Id. $\$ 7410(\mathrm{a})(3)(\mathrm{A})$. 
Third, an area may be "redesignated" from PSD to nonattainment, or vice versa, and thus come under different statutory provisions. ${ }^{60}$

Fourth, the EPA may amend the NAAQS on which the SIP was built. ${ }^{61}$ To the extent the amendment results in a need for more controls, they must be imposed; to the extent it would allow existing controls to be relaxed, the states may elect to relax them. ${ }^{62}$ If the EPA adopts a completely new NAAQS, the states must submit corresponding new SIPs.

Given the incomplete and evolving state of our knowledge in the area, it is very likely that the conditions for making these changes will frequently be met. The availability at any time of a number of other minor, source-specific variances further increases the likelihood of change. ${ }^{63}$

60 "A State may from time to time review, and as appropriate revise and resubmit, the list [of attainment, nonattainment, and unclassifiable areas] required under this subsection. The Administrator shall consider and promulgate such revised list in accordance with this subsection." Id. $\$ 7407(\mathrm{~d})(5)$.

61 "Not later than December 31, 1980, and at five-year intervals thereafter, the Administrator shall complete a thorough review of the . . . national ambient air quality standards . . . and shall make such revisions . . . and promulgate such new standards as may be appropriate." Id. $\$ 7409$ (d)(I).

The EPA did not meet the 1980 deadline for revising the five NAAQSs in existence when the 1977 amendments were enacted. Although amendments to the ozone standard were promulgated in 1979, 44 Fed. Reg. 8,220 (1979) (codified at 40 C.F.R. $\$ 50.9$ (1980)), those for carbon monoxide have only been proposed, 45 Fed. Reg. 55,066 (1980). A second draft of a proposed "criteria document" for sulfur oxides and particulates has recently been made available for public comment. 46 Fed. Reg. 15,569 (1981). The Agency will have to rewrite that document in light of the comments before revisions to the standards themselves can even be proposed.

62 The statute requires each state to submit a SIP to the EPA within nine months after any "revision" of a primary or secondary NAAQS. 42 U.S.C. $\$ 7410$ (a)(1) (Supp. III 1979). This command is echoed by a subsequent clause requiring each SIP to provide for its own amendment "from time to time as may be necessary to take account of revisions of [any] national primary or secondary standard." Id. $\$ 74 I 0(\mathrm{a})(2)(\mathrm{H})$.

Although on the surface these provisions apply whether an NAAQS is loosened or tightened, a state is always free to adopt a SIP more stringent than the national standards require. Id. \$7416. See Union Elec. Co. v. EPA, 427 U.S. 246, 263-64 (1976). Accordingly, the EPA would interpret state inaction after a standard had been loosened as indicating that state's desire to invoke this authority. This circumstance would not call for any further moves by the Agency. By contrast, state inaction after a standard had been tightened would almost certainly leave the SIP inadequate to meet those new standards, and this would call for corrective measures on the EPA's part.

63 Congress, in addition to the basic regulatory mechanism described above, has also provided a long list of source-specific variances (and, occasionally, tightening changes) that can in effect amend other Clean Air Act requirements.

1. A source may obtain a four-year waiver of new source performance standards in order to enable the installation of innovative technology. 42 U.S.C. $\$ 7411(j)$ (Supp. III 1979). 
[Vol. 129:1059

\section{The Double Key and Its Consequences}

In addition to setting the possible routes for substantive changes in regulatory requirements, the Act regulates the procedure by which such changes are made. It provides that a state may change a SIP only "after reasonable notice and public hearings." 04 Almost invariably these changes are made through state rulemakings subject to state administrative procedure acts. ${ }^{65}$ In addition, the state, after completing its own procedures, must submit the result to the EPA for its approval. Upon receiving a state plan or plan revision, the EPA publishes it in the Federal Register for public comment, as required by the federal Administrative Procedure Act. $^{66}$ After considering the comments, it decides

2. A source may obtain a two-year waiver of a deadline for meeting hazardous air pollutant requirements, conditioned in part on operating satisfactory interim controls. Id. $\$ 7412(\mathrm{e})(\mathrm{I})(\mathrm{B})(\mathrm{ii})$.

3. A source may receive a "delayed compliance order" extending the time allowed it for meeting SIP requirements. These may be granted because the source will shut down soon, id. $\$ 7413(\mathrm{~d})(3)$, or because the Department of Energy has ordered it to convert to coal from some other fuel, id. $\$ 7413$ (d) (5)(A), or to allow the installation of "innovative" control mechanisms, id. $\$ 7413$ (d) (4), or simply because the source is "unable to comply" with applicable requirements, id. $\$ 7413(\mathrm{~d})(1)$. In each case the source must adopt interim controls and a schedule for eventual full compliance.

4. Lead, zinc, and copper smelters may receive "nonferrous smelter orders" greatly extending (upon certain conditions) the time allowed for coming into compliance with other provisions of the Act. Id. $\$ 7419$.

5. To avoid local unemployment in the coal industry, major sources may be ordered to burn only "locally or regionally derived coal or coal derivatives," and to enter into coal and emission control system contracts to enable such burning. Id. $\$ 7425$.

6. The EPA may also order major sources to install additional controls to abate their effects on air quality in states other than the one in which they are located. Id. $\$ 7426$.

7. Major sources may be required to install "best available retrofit technology" to correct pollution-caused visibility impairment in areas such as national parks and monuments. Id. $\$ 7491$.

6442 U.S.C. $\$ 7410$ (Supp. III 1979).

65 See Currie, State Pollution Statutes, 48 U. Crr. L. Rev. 27, 44 (1981).

66 The courts of appeals initially divided on the precise question of whether EPA approval of a state SIP submission is "rulemaking" subject to the notice and comment procedures of 5 U.S.C. \$553 (Supp. III 1979). Compare Buckeye Power, Inc. v. EPA, 481 F.2d 162, 170-71 (6th Cir. 1973) (EPA approval of state plan is rulemaking under \$553) with Indiana \& Mich. Elec. Co. v. EPA, 509 F.2d 839, 846-47 (7th Cir. 1975); Duquesne Light Co. v. EPA, 481 F.2d I, 8-9 (3d Cir. 1973), and Appalachian Power Co. v. EPA, 477 F.2d 495, 500-03 (4th Cir. 1973) (procedures set forth in $\$ 553$ do not apply to EPA approval of state plan).

The Supreme Court has never settled the matter. However, since these cases were decided the EPA has concluded that its approval of state submissions requires the use of rulemaking procedures. In five recent cases, various courts of appeals have accepted this concession and have made it the foundation of their decisions on the procedures required for EPA approval of attainment or nonattainment designations under the Clean Air Act. 42 U.S.C. $\$ 7407$ (d) (Supp. III 1979). The 
whether the state submission conforms, entirely or in part, to the requirements of the Act. To the extent that it does, the EPA publishes a final rule approving the plan, which then becomes enforceable as federal law. ${ }^{67}$

In other words, any change that a state wants to make in a SIP, no matter how routine, requires both state and EPA approval, and, generally, two rounds of public notice and comment. Both actors must turn the key before any new requirement is established. Most of the work on the EPA's side is handled by its ten regional offices. ${ }^{68}$ In these offices, the double-key system compels the EPA staff responsible for SIP revisions to spend a lot of time simply pushing paper. Any regulatory system as complicated as a SIP for an industrial state demands constant change. Requiring notice and comment and affirmative approval even for routine changes that the state has approved results in a substantial diversion of staff time to considering those changes. The costs in state and industry time of shepherding SIP revisions through the EPA must be equally substantial.

In short, the existing SIP system combines two vices. Because of continuously evolving knowledge, its scientific and technical foundations are perpetually subject to change. The statute, however, provides no mechanism for scheduling any regulatory reactions to new scientific understandings. The regulatory changes that are proposed in response to them are therefore frequently unpredictable and disruptive. On the other hand, the double key makes implementing proposed changes extraordinarily difficult. The consequences of these two organizational defects are examined in the following sections.

EPA lost three of those cases for its failure to follow $\$ 553$ procedures; in the two others, the court found that the Agency had "good cause" for omitting those procedures. Compare New Jersey v. EPA, 626 F.2d 1038 (D.C. Cir. 1980); U.S. Steel Corp. v. EPA, 595 F.2d 207 (5th Cir. 1979), and Sharon Steel Corp. v. EPA, 597 F.2d 377 (3d Cir. 1979) with Republic Steel Corp. v. Costle, 621 F.2d 797 (6th Cir. 1980) and United States Steel Corp. v. EPA, 605 F.2d 283 (7th Cir. 1979).

If rulemaking procedures are required for the approvals of state designations, which only begin the regulatory process that leads to binding requirements, $a$ fortiori they are required for the approvals of state SIPs, which actually establish those requirements.

67 See note 85 infra.

68 Each state in the United States is located in one of the ten EPA "Regions," headquartered in Boston, New York, Philadelphia, Atlanta, Dallas, Kansas City, Chicago, Denver, San Francisco, and Seattle. The regional office corresponding to a given state is responsible for ensuring that EPA programs are carried out satisfactorily in that state, either through the state's own programs, or, where necessary, by superseding federal action. Review of state SIP submissions, and preparation of substitute provisions for the EPA to promulgate where necessary, fit naturally into this basic assignment. 


\section{B. Resistance to New Knowledge}

As we have seen, evolving scientific and technical knowledge will frequently suggest that a SIP's control requirements for a particular source, or group of sources, are either more lenient or are stricter than the statute requires. ${ }^{69}$ If these requirements are found to be too lenient, the letter of the Act requires the control agency to promptly tighten the SIP. No regulatory system-and no regulated industry-however, can function acceptably if it is subject to continual, unpredictable tightening of requirements. The EPA has shown, therefore, an increasing tendency, at least in the short term, to look away from information calling for tighter SIP requirements, unless it is truly dramatic. ${ }^{70}$ That tendency is bound to increase as the deadline for attaining the standards draws closer, because that deadline will make changes more disruptive and less practical by shortening the time allowed for compliance.

If SIP requirements are too strict, it will of course not be comparably difficult for the system to accommodate relaxation, although some confusion may result. This creates in the SIPs a procedural tendency towards a gradual loosening of control requirements without reference to the technical merits involved. The somewhat ironic result, then, of the Act's requirement that all new knowledge be reflected promptly in emissions controls is a tendency to ignore or discount many types of new knowledge.

The "double-key" procedural framework only makes this problem worse. By making changes cumbersome, time-consuming, and costly, it further reduces, almost by definition, the system's ability to adapt to new knowledge. In addition, if the EPA falls behind in processing SIP changes-and it is behind at present-the assimilation of new knowledge is further delayed. ${ }^{11}$

69 See notes 58-63 supra \& accompanying text.

70 Under the EPA's "bubble" policy, sources can shift emissions from points where control costs are high to points where they are low as long as no adverse impact on air quality results from the reallocation. See text accompanying notes 25-28 supra. The EPA originally required "modelling" of many of these changes to verify the lack of adverse impact. However, when modelling results began to show that in many cases not only the suggested new pattern of emissions, but the existing one as well, violated air quality requirements-thereby suggesting a legal duty to impose more control-the EPA significantly revised its modelling requirements. See Memorandum from David Hawkins, Assistant Administrator for Air, Noise, and Radiation, to EPA Regional Administrators (August 14, 1980) (on file with the University of Pennsylvania Law Review).

71 The National Commission on Air Quality confirmed the existence of approval delays and identified them as a source of friction in the statute. "In some cases, the delay in EPA approval of state-submitted revisions to the [state implementation] plans causes the regulatory portions of a federally enforceable plan to differ from 


\section{G. Economic Inefficiency}

As discussed, economists have linked economically efficient pollution controls to a market-based system..$^{72}$ In the context of the Clean Air Act, as a practical matter this probably means some form of "pollution rights" approach. ${ }^{3}$ That approach would place two distinct procedural demands on any system implementing it. First, because a basic purpose of the market approach is to replace general standards with individual emission limits that reflect source-specific costs, the regulatory system that implements it must also function in terms of source-specific requirements. Second, because every trade in pollution rights must change those source-specific limits, the efficiency gains of a market approach will not be fully realized unless it is in practice easy to make the regulatory changes needed to reflect those market choices.

Under the current statute, the source-specific monitoring and control requirements needed to make a market system effective must be processed as SIP revisions through the double key in order to allow formal EPA review and federal enforcement. Any active trading system among the country's 200,000 regulated sources of air pollution ${ }^{74}$ would certainly generate more transactions than the present SIP mechanism could process in any reasonable time. Indeed, even today the need to process "bubble" and "offset" trades as SIP revisions greatly obstructs the growth of these transactions. ${ }^{75}$

This problem is exacerbated by a further characteristic of the existing SIPs. The Act has never provided any set form or format for SIPs or SIP provisions. Many states responded to this latitude, when SIP submissions were first required in 1971, by simply compiling their state air pollution control statutes, regulations, codes, ordinances, and possibly some permits, and submitting the whole bundle, along with the minimum changes necessary to meet the Act's standards, to the EPA. Congress, in 1977, reacted by requiring the EPA to compile, summarize, and publish annually the

the regulations enforced by the state." NAT'x Commssron, supra note 12, at 2.1-15. See also id. 3.2-30-31.

72 See text accompanying notes 21 \& 22 supra.

73 See notes 23-28 supra \& accompanying text.

74 This estimate of the number of regulated sources is taken from undated EPA briefing materials supplied to the U.S. Senate Environment \& Public Works Committee (Winter 1981) (on file with the University of Pennsylvania Law Review).

75 Nat's Comnission, supra note 12 , at 2.1-84-85. 
regulatory requirements of each SIP. ${ }^{70}$ The new submissions required by the 1977 amendments, however, have swamped any potential beneficial effects. One letter described the Oregon SIP as "a jumble of unindexed masses of material . . approximately 2000 pages long, including 1979 revisions of nearly 1000 pages. There is no index and only a brief table of contents." 77 It added that "[t]he SIPs of other states are no better." 78

Broadly worded generic provisions are plainly ill-suited to provide the type of source-specific controls and data required by a "pollution rights" market. Absent such controls, trading would be difficult to police and abuses would be likely. Less dramatically, the system would be inefficient, both in supplying information to potential traders and in recording actual transactions.

\section{Procedural Complexity}

In addition to possessing the mechanical and policy defects just mentioned, the double-key system is constructed, the pieties of the statute notwithstanding, ${ }^{79}$ on an expensive distrust of the states. There is little purpose in having a federalized regulatory scheme

7642 U.S.C. $\$ 7410$ (h) (Supp. III 1979).

${ }^{77}$ Letter from John E. Bonine and Gary Kahn to Douglas M. Costle (April 18, 1980), at 6 (copy on file with the University of Pennsylvania Law Review). Mr. Bonine was the EPA's Associate General Counsel for Air Quality in 1976 and 1977 and worked on the Clean Air Act as a staff attorney from 1972 until 1975.

78 Id.

Recent actions by the Office of the Federal Register provide additional support for Mr. Bonine's remarks. The Administrative Procedure Act, 5 U.S.C. $\$ 552(\mathrm{a})(1)$ (1976), provides that material with regulatory effect must either be published verbatim in the Federal Register or incorporated by reference with the approval of the Director of the Office of the Federal Register. See Appalachian Power Co. v. Train, 566 F.2d 451 (4th Cir. 1977). Because the publication of SIPs thousands of pages long in the Federal Register is plainly impractical, the EPA has always incorporated state SIPs by reference. About a year ago, however, the Director refused to allow this practice to continue until the SIPs were submitted in a more organized form. This directive, which the Agency has complied with, has never been reduced to writing.

The condition of the state SIPs has also been criticized by the National Commission on Air Quality. See Nar'x Commission, supra note 12 , at $2.1-5$, 3.2-30-31.

The lack of specificity in the SIPs extends to the substance of their requirements as well as to their form. For example, in Friends of the Earth v. EPA, 499 F.2d 1118, 1123-24 (2d Cir. 1974), the EPA's approval of a plan to limit traffic by reducing parking was challenged as overly broad. The Second Circuit upheld the EPA's action, although the plan stated only that "it is estimated that available parking spaces also should be reduced by 30 to 40 percent," and did not specify a precise approach. A year later, in Friends of the Earth v. Carey, 535 F.2d 165, 171 n.7, 180 (2d Cir. 1976), the Second Circuit directed a district judge to enforce by injunction this provision of the plan.

79 See note 92 infra. 
without some central check on state action. The double key, however, assumes that formal, documented, public review of every state action is always needed to carry out the law. It would be more appropriate to the design of a federalized regulatory system to structure control requirements around the assumption that states will generally do the right thing, and that only the exceptions need be subjected to detailed public review. Unfortunately, under the existing system, it is precisely the low priority changes, involving innocuous changes or housekeeping matters, that are most slowly processed. The statute paradoxically creates the greatest delay in those areas that are most routine.

All the difficulties described above arise out of the simple mechanics of establishing SIPs and keeping them current. If legal conflict and resistance are taken into account, relations between jurisdictions grow even more intricate. Although probably no federalized regulatory statute can avoid such complexities altogether, the present approach makes them worse through its use of excessively tight deadlines and its lack of any mechanisms for scheduling or channeling change. More specifically, two varieties of problems can arise. First, the legal foundations on which a state built its SIP can change after the EPA has approved it. Second, a state, through inaction, can compel the EPA to promulgate a SIP on its own.

\section{Problems with State SIPs}

The Act requires that any state SIP submission be adequately supported by state law standing alone, and that this support be documented. ${ }^{80}$ Once approved by the EPA through Administrative Procedure Act procedures, however, a state submission becomes federally enforceable and, on its federal side, can be changed only with EPA approval. It therefore looks very much like a federal regulation.

This dual nature of SIPs creates unavoidable conceptual diffculties. What state law authorizes or commands may not be completely clear, and laws of course can change. The EPA may therefore base its approval of a state submission on a simple misunderstanding of state law, an administrative interpretation of a

80 The EPA may not approve a state SIP submission unless it "provides . . necessary assurances that the State will have adequate personnel, funding, and authority to carry out such implementation plan ...." 42 U.S.C. $\$ 7410$ (a)(2)(F) (Supp. III 1979) (emphasis added). 
state statute or regulation that the state courts then reject, a case that is overruled, a statute that is amended, or regulations that are remanded for being, for example, too expensive, technologically infeasible, or procedurally deficient. In such instances, the statutory premise that the SIP represents the final judgment of the state has been invalidated. Yet the requirement will have been federally adopted like any other rule, and will not have been rejected by a federal court. The courts have not definitively settled whether a federally approved state SIP provision that has lost effect on the state level remains in effect as federal law. Under the current law, good arguments exist on each side.

The position that the SIP remains federally binding is probably the only one that is consistent with a rapid national effort to place major new controls on air pollution through SIPs. SIPs are statewide regulatory nets that can easily take five years or more to bargain, promulgate, litigate, and amend to complete acceptability at the state level. ${ }^{81}$ Because SIP provisions are often phrased in general terms, legal action overturning a requirement may, even if prompted by one source's circumstances, call into question the validity of the requirements for many other sources that never raised a protesit. If SIP amendments took effect on the federal level at the same time they became effetcive at the state level, a state might defer effective control indefinitely by amending its regulations as soon as they begin to bite. In most cases, the EPA would need several years to promulgate a plan of its own for the missing portions. Moreover, because the Act always allows a state to displace a federal plan by submitting satisfactory requirements of its own, ${ }^{82}$ the EPA, despite its statutory duty to act quickly, has every bureaucratic reason to slacken even this slow pace whenever a state gives somewhat believable assurances of future self-correction. Finally,

81 When, in 1972, Ohio failed to submit a satisfactory SIP to control sulfur oxides, as the 1970 amendments required, the EPA took until 1976 to promulgate a substitute plan. Not until 1978 were the ensuing legal challenges resolved, allowing enforcement of the plan as a practical matter. Cleveland Elec. Illuminating Co. v. EPA, 572 F.2d 1150, 1152-56 (6th Cir. 1978).

Similarly, when the EPA found a portion of Idaho's 1972 submission inadequate, it did not promulgate a substitute until 1975, 40 Fed. Reg. 53,584 (1975). The substitute was itself overturned by the courts two years later. Bunker Hill Co. v. EPA, 572 F.2d 1286 (9th Cir. 1977).

82 The Act does not state this conclusion directly. It follows logically, however, from the provisions requiring the EPA to approve any state submission that meets the minimum requirements of $\$ 110$. See note 59 supra. Under this language a state could displace a federal promulgation by submitting satisfactory regulations of its own, together with a statement that these regulations would apply instead of any earlier promulgation. The package as a whole would meet the statutory test and the EPA would be required to approve it. 
the lack of any mechanism for scheduling SIP changes invites continual efforts at legislative or regulatory amendments. All of these considerations converge to increase the disruptive potential of litigation or other legal change at the state level and to put pressure on the EPA to find a way to contain it.

The major argument against keeping in effect at the federal level SIPs that have been rejected by a state is that doing so could establish regulatory requirements effectively shielded from judicial review. The Supreme Court has established that, because states are always free to choose air quality that is cleaner than required by the national standards, the EPA may not disapprove a state SIP that is stricter than needed to attain those standards. Accordingly, in deciding whether to approve a state SIP, the Agency may not consider whether its requirements are stricter than necessary, or even whether they are so strict as to be technologically or economically infeasible. ${ }^{83}$ Where the state law supporting those stricter standards falls, the logic behind that argument falls with it. Yet if those standards have meanwhile been approved by the EPA, they may well stay on the books for a year or more, even if the EPA intends to change them.

The EPA has dealt with this dilemma through an understandable compromise. The Agency has represented to various federal courts that if a state court rejects a SIP provision, the EPA will amend the SIP if the state does not. ${ }^{84}$ Where the legislature or a state agency has made the change at issue, however, the EPA has refused to acknowledge it if it would make the SIP inadequate.

\section{Problems with EPA SIPs}

If a state SIP submission does not meet the requirements of the Act, the EPA must disapprove it. ${ }^{85}$ If the revision in question

83 The Administrator's position is that he has no power whatsoever to reject a state implementation plan on the ground that it is economically or technologically infeasible. . . After surveying the relevant provisions of the Clean Air Act Amendments of 1970 and their legislative history, we agree that Congress intended claims of economic and technological infeasibility to be wholly foreign to the Administrator's consideration of a state implementation plan.

Union Elec. Co. v. EPA, 427 U.S. 246, 256 (1976).

84 [P] etitioners have a right to challenge the reasonableness of state plans in the state courts, and as the respondent [EPA] concedes, if "part of a state implementation plan is held invalid by a state court, the state would have to revise that part. Should the state fail to do so, the Administrator must propose and promulgate a revision."

Indiana \& Mich. Elec. Co. v. EPA, 509 F.2d 839, 847 (7th Cir. 1975).

85 Section 110 (a) (2) of the Act requires the EPA to "approve or disapprove" any state SIP within four months after the date required for its submission, and 
was not necessary to satisfy those requirements, the EPA disapproval ends the matter, though the state remains free to resubmit the revisions after curing the deficiencies that the EPA identified.

If the submission in question is necessary under the statute, however, then upon disapproving it the EPA must take regulatory action on its own to cure the deficiencies. Specifically, after disapproving the state submission it must publish proposed regulations setting forth an adequate SIP. ${ }^{86}$ That proposal will be subject not to the normal Administrative Procedure Act procedures, but to somewhat more elaborate notice-and-comment requirements mandated by the Clean Air Act. ${ }^{87}$

A state may also fail to amend its SIP in a way that the statute requires. If this failure extends beyond sixty days after the EPA has formally called for a "SIP revision," the statute allows the Agency to promulgate the necessary provisions on its own. ${ }^{88}$ The Act appears to require an EPA-promulgated SIP, unlike a state SIP, to be no more stringent than necessary to achieve the statutory goals, ${ }^{89}$ and subjects the agency's determinations in pursuit of this

then lists the findings required for approval. 42 U.S.C. $\$ 7410$ (a)(2) (Supp. III 1979).

86 The Administrator shall ... promptly prepare and publish proposed regulations setting forth an implementation plan, or portion thereof, for a State if-

(A) the State fails to submit an implementation plan which meets the requirements of this section,

(B) the plan, or any portion thereof, submitted for such State is determined by the Administrator not to be in accordance with the requirements of this section, or

(C) the State fails, within 60 days after notification by the Administrator or such longer period as he may prescribe, to revise an implementation plan ... [in response to a finding that the existing plan is inadequate or in response to a new or changed NAAQS].

42 U.S.C. $\$ 7410$ (c)(1) (Supp. III 1979).

87 See id. $\$ 7607$. Although EPA promulgation of SIPs is explicitly made subject to these special procedures, approval or disapproval of state submissions is not. See id. $\$ 7607$ (d) (I).

88 See note 86 supra.

89 Neither the courts nor Congress have definitively resolved this issue, but the weight of judicial precedent supports holding the EPA to the minimum standards that will satisfy the statute. Union Elec. Co. v. EPA, 427 U.S. 246 (1976), which held that the EPA could not reject a state SIP for overstringency, did not address this point. The Court's conclusion, however, relied on the argument that the states could, and presumably would, consider issues bearing on overstringency in drawing up the SIP. Id. 266-67. When the EPA promulgates a SIP it acts in the state's place, and therefore its SIP shoud reflect that same consideration.

In addition, the Court, in reserving the issue, cited two appellate opinions suggesting that such consideration is required. Id. $261 \mathrm{n.7}$ (citing District of Columbia v. Train, 521 F.2d 971 (D.C. Cir. 1974); South Terminal Corp. v. EPA, 504 F.2d 646 (1st Cir. 1974)). Other lower courts have reached the same result. 
end to review in the courts of appeals under the "arbitrary or capricious" standard normally used for agency regulations. ${ }^{90}$ EPApromulgated SIPs therefore approach the character of purely federal regulations. States are free to enforce EPA promulgations in their own courts if they wish, but generally have no obligation to do so. ${ }^{91}$ Both the statute ${ }^{92}$ and EPA policy, ${ }^{93}$ however, strongly favor state, not federal, action to establish SIP requirements. Beyond that,

See, e.g., Texas v. EPA, 499 F.2d 289, 312-13 (5th Cir. 1974). But cf. Cleveland Elec. Illuminating Co. v. EPA, 572 F.2d 1150, 1164-65 (6th Cir. 1978) (wide latitude granted the EPA in determining the feasibility of proposed controls).

9042 U.S.C. $\$ 4607$ (d) (9) (Supp. III 1979).

91 Any general attempt to force state and local legislative and executive branches to use their governmental powers to carry out the Clean Air Act would raise serious constitutional questions. See National League of Cities v. Usery, 426 U.S. 833 (1976). The EPA has never asserted such authority.

No one disputes, however, that a state or local government may be federally compelled to clean up a source of pollution that it owns itself. The Agency has used this logic to argue that these governments, as owners of highways, without which automobile traffic would not be possible, may be compelled to take steps to reduce automobile emissions, because those highways constitute a "but-for" cause of the emissions. See 38 Fed. Reg. 30,632-33 (1973).

This argument met a mixed reception in the courts of appeals. See Maryland v. EPA, 530 F.2d 215 (4th Cir. 1975); District of Columbia v. Train, 521 F.2d 971, 981-95 (D.C. Cir. 1975); Brown v. EPA, 521 F.2d 827 (9th Cir. 1975); Pennsylvania v. EPA, 500 F.2d 246 (3d Cir. 1974). The issue was appealed to the Supreme Court, which declined to decide it. EPA v. Brown, 431 U.S. 99 (1977).

92 The Act begins with a finding that "the prevention and control of air pollution at its source is the primary responsibility of States and local governments." 42 U.S.C. $\$ 7401$ (a) (3) (Supp. III 1979). This theme echoes through the legislative history of the 1977 amendments. See, e.g., H.R. REP. No. 294, supra note 40 , at $1,7-8,10,11,12,15-16,25-26,141,143,146-52,178-79,195,197-201$, 201-02, 211, 213-14,313,326, reprinted in [1977] U.S. Code CoNG. \& AD. NEwS 1077, passim; S. REP. No. 127, 95th Cong., 1st Sess. 2, 10-12, 15-16, 29-31, 57-58 (1977). Although the actual provisions of the law often "render quite hollow the statutory catechism that pollution control is primarily a state responsibility," Currie, supra note 36 , at 1469 , the nominal preference for state action still creates pressure for delegation to states where that is allowed.

93 This policy cannot be taken, of course, to the point of approving inadequate state SIPs. Under the Civil Service Reform Act, 5 U.S.C. \$\$1101-\$913 (Supp. III 1979), a federal employee above a certain rank must enter into "performance agreements" with his or her immediate superior. These are meant to be contracts spelling out what the two expect the employee to accomplish in the next year. Those who perform exceptionally well in fulfilling these agreements are eligible for cash bonuses. Those who perform poorly can be fired. See id. $\$ \S 4301-4305$; id. $\$ \$ 4311-4315$. A number of performance agreements in one EPA region proposed to evaluate employees in charge of SIP review solely by the number of SIPs they approved. The approach was dropped after the EPA's General Counsel pointed out that the law requires the EPA to disapprove inadequate SIPs, and that unbiased compliance with this provision could hardly be expected from persons whose salary and job security rested on the absence of disapprovals. Memorandum from Michele Beigel Corash, General Counsel, EPA, to David Hawkins, Assistant Administrator for Air, Noise and Radiation, and William Drayton, Jr., Assistant Administrator for Planning and Management (March 4, 1980) (copy on file with the University of Pennsylvania Law Review). 
EPA promulgation brings with it an additional problem. As noted earlier, when a state promulgates a plan, it can control pollution levels as tightly as it likes, but when the EPA promulgates one, it probably must be as lenient as it can be while achieving the statute's goals. What happens when the Agency promulgates a plan that later data suggest is stricter than absolutely necessary? The obvious answer-that the EPA must revise the plan to conform to the test applied at promulgation-is not as clear as it seems. Rigorously followed, it would permanently label each piece of a SIP with the name of the level of government that promulgated it, perhaps many years ago. At the logical extreme, the different duties associated with the different labels would persist even though SIP segments of state and federal origin might be so closely related that it would be desirable or necessary to amend them together, and even though the state might in effect have adopted the federal promulgation by taking it over and enforcing it. The EPA would have a duty to amend and keep current those portions of a plan that it had originated, but not those that the state had originated. Unfortunately, any attempt to draw back from these consequences blurs the clear line that makes the problems easy to handle conceptually.

\section{The Permit Theme}

Title I of the Glean Air Act employs permits as vehicles for its regulatory requirements almost as extensively as it uses SIPs. While the SIP provisions fit together into a scheme possessing at least conceptual unity, however, the permit requirements, largely 1977 additions to the statute, have never been spliced into its basic structure. Although the problems that arise in the use of permits are less dramatic and have fewer implications than those created by SIPs, their practical significance is equally great.

\section{a. What Permits Are Based On}

Title I explicitly provides for two major types of permit programs. First, it uses permits to ensure that all new sources of air pollution above a certain size meet certain minimum, technologybased levels of control, and that they do not interfere with the statute's overall objectives. Second, but in a far less decisive manner, it calls for some permit programs to control existing sources. More particularly, the Act requires every newly constructed "major facility" in both nonattainment and PSD areas to obtain a permit. The exact threshold differs between the two 
types of areas; ${ }^{94}$ in any event, only a relatively small number, even of new sources, falls under this requirement. ${ }^{95}$

To obtain a permit in a nonattainment area, a source, in addition to meeting other conditions, must install controls capable of matching the strictest standards imposed on the industry elsewhere, and must show that the new emissions it will contribute after controls will not interfere with its area's progress toward attainment. ${ }^{96}$

94 Under the PSD program, any source with the "potential to emit" 100 tons or more each year of "any air pollutant" must obtain a permit if it falls in one of 28 industrial categories listed in the statute. 42 U.S.C. $\$ \$ 7475$ (a), 7479 (Supp. III 1979). The list includes steam electric power plants, industrial boilers, coal cleaning plants, oil refineries, and copper smelters. Id. $\$ 7479(1)$. Sources not specifically included in the list must obtain permits if they have the "potential to emit" 250 tons or more per year of any air pollutant. Id. $\$ 7479(1)$.

In nonattainment areas, review extends to any source of whatever nature with the potential to emit 100 tons annually. Id. $\$ \$ 7502(b)(6), 7602(j)$.

The D.C. Circuit has ruled that these numerical cutoffs must be measured against a source's emissions after installation of emission controls, not against what the emissions would have been absent such controls. Alabama Power Co. v. Costle, 636 F.2d 323, 353-54 (D.C. Cir. 1980).

It has also ruled, however, that a permit is required if the source would exceed the threshold for any pollutant, whether or not it is one for which the area is classified "nonattainment" or "PSD," and whether or not it is one for which an NAAQS has been established. Id. 405-06.

95 Though no precise figures are available, EPA staff familiar with the program estimate that around 2,000 new sources a year fall under these permit requirements, while at least ten times that many new sources are created annually.

Under the statute, any "modification" of a major source must also be reviewed. The D.C. Circuit has greatly expanded the potential reach of this requirement by holding that any modifications that increase emissions above a "de minimis" level must be reviewed, and by rejecting the EPA's limitation of the requirement to "modifications" that themselves increase emissions by more than the 100 or 250 ton per year statutory thresholds. Alabama Power Co. v. Costle, 636 F.2d 323, 399-400 (D.C. Cir. 1980).

Whatever the legal merits of the D.C. Circuit's position, it certainly seems perverse from a policy standpoint for two reasons. First, it creates a different threshold for the review of modifications than for the review of new sources, even though the impact on air quality of a given emissions increase would be the same in either case. Second, if there must be a difference in standards, it seems unreasonable to set the threshold lower for modifications of existing sources, where the air quality impact will already be known in general and where further control through retrofitting may be difficult, than for new sources, where the air quality impacts will be largely unknown and where a wider range of control options is probably available.

${ }^{\circ}$ More specifically, an applicant for a permit to construct in a "nonattainment" area must:

1. Demonstrate that even if the new source is constructed, thereby causing new emissions, emissions from other sources will be reduced by more than enough to offset those new emissions and thus continue the area's "reasonable further progress" toward the standards, 42 U.S.C. $\$ 7503$ (1) (Supp. III 1979);

2. Demonstrate that all other major sources in the same state owned by the same person are in compliance with air pollution requirements, or on a binding compliance schedule, $i d$. $\$ 7503(3)$;

3. Demonstrate that the applicable SIP is being enforced, $i d$. $\$ 7503(4)$, and

4. Install technology capable of controlling emissions to the "lowest achievable emissions rate," $i d$. $\$ 7503(2)$. The statute defines this rate as the tightest feasible 
A permit for a PSD area can be issued only if the source, among other things, installs the "best available control technology," 97 analyzes in detail its own impact on air quality, and shows that its added emissions would not increase pollution in the area above the statutorily specified "increments." 98

Beyond these provisions for new sources, the statute also requires all SIPs to contain "a program to provide for the . . . regulation of the modification, construction and operation of any stationary source . . . as necessary to assure . . . that national ambient air quality standards are attained and maintained." 99 This murky language apparently allows the EPA to require permit programs for attainment and maintenance beyond what the statute explicitly calls for. The Agency has not vigorously pursued this possibility. ${ }^{100}$

\section{b. Procedures for Permits}

The Act requires only an informal public hearing before PSD permits are issued, ${ }^{101}$ and imposes no procedural requirements at all on the issuance of operating permits or permits in nonattainment areas. Although it contemplates state issuance of all these permits, it provides no clearly available mechanism for EPA oversight along the lines of the double-key requirement for SIPs. ${ }^{102}$ Congress could

control required by any SIP anywhere for that class of source, or the tightest control attained in practice, whichever is lower. Id. $\$ 7501(3)$.

97 Id. $\$ \$ 7475$ (a) (4), (a) (8).

98 More specifically, under the statute, an applicant for a PSD permit must: (a) (6);

1. Analyze the projected direct and indirect air quality impacts, $i d . \$ \$ 7475(\mathrm{e})$,

2. Agree to install any monitoring equipment necessary to determine the actual air quality impact, id. $\$ 7475$ (a) (7);

3. Demonstrate that the new source will not violate any requirement of the Act, whether or not related to the PSD program, id. $\$ \$ 7475(\mathrm{a})(3),(\mathrm{a})(5)$, and

4. Install the "best available control technology" (BACT), id. $\$ \$ 7475$ (a)(4), (a) (8). This in turn is defined as the maximum achievable reduction taking into account "energy, environmental and economic impacts and other costs." Id. $\$ 7479(3)$. In no event, however, can BACT be less stringent than any standard established under $\$ \S 111$ or 112 of the statute. Id. $\$ 7479(3)$. See note 36 supra. 99 Id. $\$ 7410$ (a)(2)(D).

100 Nevertheless, according to a study done for the EPA, 46 states have some form of air pollution control permit program already, and 24 states regulate both old and new sources through permits. GCA Corporation, Summary of Existing State Operating Permit Program Regulations 3 (1979). See also Currie, supra note 65 , at $66,65-69$ (listing the advantages of permits and stating that "nearly every state pollution statute requires permits for the construction or operation of potential sources, or for both.").

10142 U.S.C. $\$ 7475$ (a)(2) (Supp. III 1979).

102 Currie, Nondegradation and Visibility Under the Clean Air Act, supra note 3 , at 62 (1980).

Section 167 of the Act allows the EPA to "take such measures, including . . . seeking injunctive relief, as necessary to prevent the construction of a major 
have included permits in the SIPs for enforcement purposes, even after dispensing with the double key, but it appears instead to have excluded permits from the SIPs completely. The text of the statute refers repeatedly to the need for SIPs to "require" or "provide for" a permit program, not for the permits themselves to be included.103 This approach suffers from two immediate practical deficiencies.

First, if a state proposes to issue a permit that does not fulfill its purpose under the federal statute, the EPA cannot readily stop it. That is true even though many permits could have a direct effect on the attainment of levels of air quality established as national regulatory goals by the Act.

Second, the statute provides a far more workable and comprehensive federal enforcement scheme for SIPs than for permits standing alone. SIPs can be federally enforced by the EPA ${ }^{104}$ or by "citizens' suits." 105 Although citizens' suits can request only injunctive relief, the EPA can request either injunctive relief or a range of civil or criminal penalties. ${ }^{106}$ Non-SIP permits, by contrast, often cannot be federally enforced at all, or can be enforced only by injunction. ${ }^{107}$

These difficulties apart, it seems philosophically inconsistent not to include permits in the SIP. A SIP is designed to include all measures needed to meet the applicable air quality goals, and it will not pass that basic test if it only sets forth a general permit

emitting facility which does not conform to the requirements of . . . [the Act's PSD provisions]." 42 U.S.C. $\$ 7477$ (Supp. III 1979). Section 304 allows citizens" suits (but not, on its face, EPA suits) against any person who attempts to construct a major source without a nonattainment or PSD permit, or who violates any term of such a permit. Id. $\$ 7604(\mathrm{a})(3)$, (f) (3). Although these provisions reach a source that builds without a permit, or that violates a permit it has obtained, they offer no mechanism to prevent a state from issuing a permit that violates the purpose of the statute. The EPA could possibly have constructed an administrative "veto" mechanism based on the language of $\$ \$ 113(\mathrm{a})(5)$ and 167, but it never seriously explored that course.

103 Id. $\$ 7410$ (a)(2)(D) ("permit program," "permit or equivalent program"); id. $\$ 7502(\mathrm{~b})$ ("The [nonattainment] plan provisions ... shall ... (6) require permits .. in accordance with section 7503 ... ."); id. $\$ 7503$ ("permit program").

Although Part $\mathrm{C}$ of title $\mathrm{I}$, concerning PSD, contains no parallel statement, it explicitly provides for notice to the Administrator of any state action respecting a state PSD permit, $i d$. $\$ 7475(d)(1)$, and contains special provisions allowing the Administrator to stop construction without a permit. Id. $\$ 7477$. These provisions would be unnecessary if permits were part of the SIP, because all SIP changes must automatically be transmitted to the EPA for approval, and comprehensive authority to enforce SIPs is conferred by $\$ 113$. Id. $\$ 7413$.

104 Id. $\$ \$ 7413,7420$.

105 Id. $\$ 7604$.

106 See $i d$. $\$ 7413(\mathrm{~b})$ (injunction or civil penalty); id. $\$ 7413$ (c) (criminal penalty); id. $\$ 7420$ (administratively assessed civil penalty).

107 See note 103 supra. 
program while omitting the individual permits themselves. Under any general program, it is the individual permits, not the program that authorizes them, that will carry the binding regulatory message. The sum of those individual terms, not the general program, will determine whether the permit program in the SIP (and thus the SIP) is adequate to clean the air or preserve its cleanliness.

Indeed, the EPA could have adopted this logic to solve the two immediate problems with permits. It could have stated that because each permit, viewed analytically, should be part of the SIP, it would have to be included in the SIP by processing through the double key. ${ }^{108}$ That would have removed any doubts about enforceability, while the review opportunity would also have allowed the EPA to disapprove those permits that did not meet minimum legal requirements. It is a testament to the unworkability of the double key that, despite these advantages to the Agency, the EPA never seriously considered extending it to all permits. Instead, it has approached those issues by an unsatisfactory compromise.

First, it promulgated a regulation stating that "all permit conditions or permit denials issued pursuant to approved or promulgated regulations for the review of new or modified . . . sources" may be enforced as part of the SIP. ${ }^{109}$ The EPA has never explained, however, how these permits become part of the SIP for enforcement purposes without going through the SIP approval process laid down by the statute.

Beyond that legal question, this approach does nothing to cure the present lack of EPA review authority. The Agency has thus been willing to allow the construction of major new sources without mandating approval of the new source regulatory requirements through the double key. It has not been willing, however, to adopt that approach where changes in the emissions requirements for existing sources are concerned. Operating permits are often included in SIPs, and if a state wishes to revise such an operating permit, the full SIP approval process must be followed. ${ }^{110}$

There is little sense in having the procedures for such similar transactions differ at all. But if there must be an illogical distinction, the present approach makes it in the least logical way. New

108 Because the statute defines a SIP as the sum of all state requirements that the EPA has approved through the double key under the broad statutory tests, this redefinition would be sufficient to include permits in the SIPs.

10940 C.F.R. $\$ \$ 52.02(\mathrm{~d}), .23$ (1980).

110 This is explicitly set forth in the EPA's "bubble" policy. 44 Fed. Reg. $71,780,71,782,71,786$ (1979). The EPA has now relaxed that requirement for cases in which the permissible conditions for individual permits can be determined by simply applying a mathematical formula. See 46 Fed. Reg. 20,554 (1981). 
sources must be of considerable size before the statute requires review, and by definition they always increase emissions. Changes in operating permits, on the other hand, can include minor emissions increases or even reductions as well as major increases. It would therefore make more sense from a pollution control standpoint to subject the former and not the latter to full SIP review. The only justification-a poor one-for the current practice is that requiring double-key approval for new sources would result in intolerable regulatory delays in the commencement of construction, while similar delays in changing requirements for existing sources are more acceptable because new construction is not involved and the cost is therefore likely to be less.

\section{c. Permits and SIPS}

Beyond the problems with the permit system itself, two other difficulties arise in considering the system's relation to the SIPs. First, permits to new sources will generally not be modified after issuance, because they set the conditions under which construction may proceed. ${ }^{111}$ A source that must get a permit, however, may also be subject to SIP provisions that the permit does not reflect. Yet the statute provides no mechanism to coordinate permit terms with applicable SIP provisions, even though the two are bound to diverge over time, as the SIPs change while the permit does not.

The second problem is that the different treatment of SIPs and permits defines a fundamental inconsistency in the statute. The requirement for a double approval of SIPs has led to great pile-ups of routine paper in EPA regional offices. At the same time, state permit decisions involving major new sources, which are far more important to national goals than are most of these SIP changes, go totally unreviewed by the EPA.

\section{A Permit-Based Glean Air Act}

Congress could greatly alleviate all of the problems discussed above by using permits issued to individual sources, not SIPs, as the major vehicles of regulation.

\section{A. The Clean Water Act as a Model}

The Clean Water Act, also administered by the EPA, rests on a permit system that has proved quite workable in practice. Indeed, 
the EPA has largely conformed the permit programs by which the Resource Conservation and Recovery Act ${ }^{112}$ and the Safe Drinking. Water Act ${ }^{113}$ will be implemented to the Clean Water Act model. ${ }^{114}$ Under the Clean Water Act, every "point source" of water pollution ${ }^{115}$ must apply for and receive a permit. ${ }^{116}$ The permit may be issued either by the EPA or by an approved state. ${ }^{117}$ To be approved, a state must show that it has full authority under state law to issue permits that satisfy federal requirements, ${ }^{118}$ and that its program for issuing permits will in fact meet basic federal standards. The Agency is entitled to object to or "veto" any state-issued permit if it acts within a specified short period.119 If a state does

112 Resource Conservation and Recovery Act of 1976, Pub. L. No. 94-580, 90 Stat. 2795. See note 30 supra.

11342 U.S.C. $\$ \$ 300 \mathrm{f}-300 \mathrm{j}(1976)$.

114 The Agency did this in its Consolidated Permit Regulations, which integrate the permit requirements under each of these statutes. See 40 C.F.R. $\$ \$ 122-124$ (1980).

115 The statute defines a "point source" as "any discernible, confined and discrete conveyance, including but not limited to any pipe, ditch, channel, tunnel, conduit, well, discrete fissure, container, rolling stock, concentrated animal feeding operation, or vessel or other floating craft, from which pollutants are or may be discharged." 33 U.S.C. $\$ 1362$ (14) (Supp. III 1979). A "pollutant" is defined as "dredged spoil, solid waste, incinerator residue, sewage, garbage, sewage sludge, munitions, chemical wastes, biological materials, radioactive materials, heat, wrecked or discarded equipment, rock, sand, cellar dirt, and industrial, municipal, and agriculture waste discharged into water." 33 U.S.C. $\$ 1362(6)$ (1976).

Specific exclusions exempt from the sweep of these definitions irrigation return flows, discharges of sewage from vessels, and certain discharges in connection with oil or gas drilling. Id.

Finally, a "discharge" is, in part, "any addition of any pollutant to navigable waters from any point source." Id. \$1362(12).

116 The Clean Water Act provides: "Except as [sic] in compliance with this section and sections 1312, 1316, 1317, 1328, 1342, and 1344 of this title, the discharge of any pollutant by any person shall be unlawful." 33 U.S.C. $\$ 1311$ (a) (Supp. III 1979). With one exception, the sections listed provide for specific regulatory requirements that may apply to a discharge. Section 1342 mirrors the list of specific provisions and makes the permit the vehicle for them by providing:

Except as provided in sections 1328 and 1344 of this title, the Administrator may, after opportunity for public hearing issue a permit for the discharge of any pollutant, or combination of pollutants, notwithstanding section 1311(a) of this title, upon condition that such discharge will meet ... all applicable requirements under sections 1311, 1312, 1316, 1317, 1318 and 1343 of this title, or . . . such conditions as the Administrator determines are necessary to carry out the provisions of this chapter.

$I d . \$ 1342(\mathrm{a})(1)$.

11733 U.S.C. $\$ 1342$ (b) (1976, Supp. II 1978 \& Supp. III 1979).

$118 \mathrm{Id}$.

119 The Act requires each approved state to provide the EPA with copies of each permit application and each permit it proposes to issue, unless the EPA waives its right to receive them. 33 U.S.C. $\$ 1342(d)(1)$ (1976). It further provides that "[n]o permit shall issue ... if [EPA] within ninety days of the date of transmittal of the proposed permit by the State objects in writing to the issuance of such permit as being outside the guidelines and requirements of this chapter." 
not correct whatever deficiencies the EPA has identified, the Agency itself can issue a superseding permit. ${ }^{120}$ All final permits, both state and federal, are equally enforceable in federal court. ${ }^{121}$ Conversely, a source's permit specifies the sum total of requirements that it must comply with under the Glean Water Act. ${ }^{122}$ Only in special cases can permit conditions be changed before the term expires. ${ }^{123}$ To allow periodic reexamination and amendment as new knowledge develops, Glean Water Act permits expire, and require renewal at intervals not exceeding five years. ${ }^{124}$

As a mechanical matter, this entire scheme could be transplanted into the Clean Air Act without significant change. Each source of air pollution would require an air pollution control permit issued either by the EPA or an approved state. The permit would contain all the Clean Air Act requirements governing that source, would generally remain constant for a fixed term, ${ }^{125}$ and would expire and be renewed at periodic intervals. ${ }^{120}$ State permits

33 U.S.C. $\$ 1342$ (d)(2) (Supp. III 1979). The EPA must specify the deficiencies, and, upon request, hold a public hearing on them. Id.

120 The Act provides that if a state does not satisfactorily revise a proposed permit to which the EPA has objected within 30 days of any hearing on that objection, or within 90 days of the objection if no hearing is held, the EPA may issue the permit itself. Id. $\$ 1342(\mathrm{~d})(4)$.

12133 U.S.C. \$1319 (1976 \& Supp. III 1979).

122 "Compliance with a permit issued pursuant to this section shall be deemed compliance, for purposes of sections 1319 and 1365 [the enforcement provisions of the Clean Water Act], with sections 1311, 1312, 1316, 1317, and 1343 . . except any standard imposed under section 1317 for a toxic pollutant injurious to human health." 33 U.S.C. \$ 1342(k) (1976).

123 The EPA's Consolidated Permit Regulations provide a list of situations in which this may be done. See 40 C.F.R. $\$ 122.15$ (1980).

124 The Clean Water Act requires all permits issued under an approved state" program to be "for fixed terms not exceeding five years," 33 U.S.C. $\$ 1342(b)(1)$ (B) (Supp. III 1979), and binds EPA permits to the same standards that govern permits under an approved state program. 33 U.S.C. $\$ 1342(a)(3)$ (1976).

${ }^{125}$ The National Commission on Air Quality has endorsed an approach that would achieve the same result by providing that, in general, control requirements for individual sources could be changed only at ten-year intervals. Nar'x ComMIsston, supra note 12, at 2.2-10-11.

128 To provide an acceptable degree of control, the threshold emission levels that make a source subject to the permit requirements might have to be dropped significantly below the present levels. See note 94 supra.

Congress, by authorizing the issuance of "general permits," could avoid the possibility that such a broad permitting requirement would snare the EPA, the states, and the regulated industries in a web of permits too numerous to handle. In effect, these would be rules covering a number of small sources, probably in the same geographical area, and subjecting them to common regulatory requirements. Yet they would be more flexible than rules usually are, because a source that did not wish to be bound by the generic provisions would potentially be able to apply for and receive a permit containing requirements tailored to its own circumstances.

Judge Leventhal first suggested this approach to the EPA in a case under the Clean Water Act, which requires all dischargers, regardless of size, to get permits. Natural Resources Defense Council, Inc. v. Costle, 568 F.2d 1369, 1381 
would be subject to federal veto within a specified short period after issuance, and the EPA could issue a superseding permit if the state did not take necessary corrective actions. All permits would be fully enforceable in federal court.

\section{B. The Immediate Advantages of a Permits Approach}

A permits approach would alleviate at least four of the current systems procedural problems. Most immediately, the permits approach would replace, with a single intermediate position, both the "double key" and the inability of the EPA to review permits. No state permits would need affirmative EPA approval, and none would be automatically exempt from review. Instead, state permits would take effect automatically unless the EPA bestirred itself to disapprove them. Further, the statute could allow, as the Glean Water Act does, ${ }^{12 \pi}$ the EPA and a state to agree to waive review of certain categories of permits. ${ }^{128}$ This would further focus EPA attention on cases that genuinely deserved it. Even without this refinement, however, the abandonment of the "double key" would eliminate the pointless delay of approving routine changes by dual state and federal proceedings, and would relieve the EPA's regional offices of a substantial volume of unproductive work.

(D.C. Cir. 1977). The EPA has since formally adopted it. See 40 C.F.R. $\$ 122.59$ (1980), promulgated at 45 Fed. Reg. 33,447 (1980). See also 44 Fed. Reg. $32,873-74,32,916-17$ (1979).

12733 U.S.C. $\$ \$ 1342$ (d) (3), (e) (Supp. III 1979).

128 The combination of a general "veto" power with the authority to waive review would allow the EPA to rely on quality control methods more sophisticated and efficient than case-by-case review of each individual permit. For example, a statistical approach based on sampling of a certain number of decisions, or intensive audits by special review teams, could be relied on instead. See Mashaw, The Management Side of Due Process: Some Theoretical and Litigation Notes on the Assurance of Accuracy, Fairness, and Timeliness in the Adjudication of Social Welfare Claims, 59 Connery L. REv. 772 (1974).

Despite the advantages, some problems involving federal-state relations would still remain. For example, an EPA Region might informally let a state know that a permit would be vetoed unless it contained certain terms. The state might then respond by making the desired changes. The federal input would have been one factor in the decision, and yet only state court review might be available. See Shell Oil Co. v. Train, 585 F.2d 408 (9th Cir. 1978); Comment, Jurisdiction to Review Informal EPA Influence upon State Decisionmaking Under the Federal Water Pollution Control Act: Shell Oil Co. v. Train, 92 Harv. L. Rev. 1814 (1979).

This problem, however, goes only to whether a litigant can always have its desired forum for challenging agency action, which is hardly a topic of major concern. In addition, exactly the same problem arises in the SIP area, and there is every reason to believe that state agencies will have more cause to heed EPA suggestions in that situation than under a permit-based scheme. To veto a permit is a major step that a regional office probably would not undertake lightly, while simply to be slow in processing a SIP revision, though much less visible, could be almost as effective in putting pressure on a state. 
Permits would also remedy the current uncertainty created by the diversity of requirements imposed on sources by the Act. Indeed, the permit itself would serve as the vehicle to coordinate these requirements because it would have to contain all of them. ${ }^{129}$ In addition, any confusion in the underlying SIPs would become somewhat less important to sources, because all obligations under the Act would be set out exclusively in the permits. Finally, the permits approach would remove questions about SIP-permit conflicts, because the permit would include all the regulatory provisions applicable to a source. Likewise, the approach would resolve questions about the enforceability of permits.

\section{The Broader Advantages of a Permits Approach}

In addition to curing the predominantly mechanical defects discussed above, a permit-based Clean Air Act would accommodate new knowledge, provide a foundation for a market-based approach, and handle federal-state relations and relations between EPA statutes more effectively than does the existing system. The following section examines the treatment of new knowledge under a permit system. It is first necessary, however, to examine how actual pollution controls could be established in such a system.

\section{A Permit System and New Knowledge}

\section{a. Basing an Ambient Statute on Permits}

Any regulatory system that relies upon individual permits faces two related requirements. First, some mechanism must be created for establishing the specific control provisions contained in particular permits. Second, the terms of individual permits must be bound together into a common and unified regulatory scheme. Both of these needs arise with particular intensity in an environ-

129 Under the Act at present, control requirements can potentially be based on a variety of ambient or technology-based calculations. Because the regulatory requirements for a plant thus can have widely differing origins, a permit would perform the very useful task of summarizing and synthesizing what those requirements mean in the concrete circumstances of an individual source. The National Commission on Air Quality has identified as a problem the present lack of such a coordinating vehicle. NAT'x Commossion, supra note 12 , at $2.1-66,3.8-2$.

In addition, this approach would be particularly useful for dealing with the narrowly focussed requirements listed in note 63 supra. Each of these provides for either a permit or a "quasi-permit"-a source-specific requirement that imposes continuing obligations. They would therefore fit more cleanly into a permit-based Clean Air Act than they do into the present structure. At present, decisions under these provisions, like SIP decisions, may be made at any time. A permit-based Act could greatly simplify matters by providing that such decisions generally bo made only at the time of issuance or renewal of a source's permit. 
mental statute based primarily upon ambient, rather than technological, standards.

Under a technology-based scheme, permit issuance proceedings can be used to determine the appropriate technology for particular sources and require its installation there. Because questions about what technology is available at what cost may look similar and have similar answers from plant to plant within an industry, addressing each permit in a separate proceeding has definite costs. It requires duplication of effort to the extent that the sources involved are similar. If different standards result, the source subject to the stricter standard can argue that it has been treated unfairly. Even given these problems, however, the control scheme would work after a fashion.

Under an ambient approach, by contrast, it is not always possible to set requirements source by source in unrelated, individual proceedings. The questions that recur among permit proceedings in an ambient system are likely to be not just similar-as with technology-based standards-but the same. The issuing agency must, for each permit proceeding, determine what the emission and pollution characteristics of a region are and what pattern of controls will bring the region to attainment, or prevent significant deterioration. Given this background, it follows that controlling sources to meet ambient requirements presents a problem that is "polycentric" in the classic sense. That is, the control requirements for source $A$ may vary depending on the requirements set for sources $B, C, D$, and so forth. ${ }^{130}$ Thus, it is impossible to grant a permit to $A$ without considering how to regulate the others.

One response to these problems could be simply to abandon the ambient approach. That, however, would also abandon much hope for efficient environmental regulation. ${ }^{131}$ The key task, therefore, is to find a way to address the problems that recur from permit to permit, or that link individual permit decisions together, under an ambient scheme. For both types of problems, the solution in principle is well established in administrative law. The control agency should issue rules, or set general principles, specifying how it will decide common or interlocking questions. Judges and pro-

130 L. Fulien, The Morariry of Law 170-77 (rev. ed. 1969); Boyer, Alternatives to Administrative Trial-Type Hearings for Resolving Complex Scientific, Economic, and Social Issues, 71 Mrch. L. Rev. 111, 117 (1972) ("Perhaps the clearest example of problems that seem 'polycentric' can be found in the field of environmental protection."); Fuller, The Forms and Limits of Adjudication, 92 HaRv. L. Rev. 353, 394-405 (1978).

131 See text accompanying notes 8-10 supra. 
fessors have urged this course for more than a generation on established agencies that, like the Interstate Commerce Commission and the Federal Communications Commission, decide many related cases. ${ }^{132}$ There is no reason not to transpose it to the relatively new field of environmental law.

More concretely, a state or the EPA would issue a general rule that established the mechanisms needed to make ambient calculations for an area. The rule would specify the applicable air quality readings, the inventory of sources, the meteorological readings, and the model. These determinations would generally bind individual permit proceedings, though some departures might be allowed in particular cases. The agency would update the general rule as new knowledge developed, but the changes would have prospective effect only. Except in unusual cases, ${ }^{133}$ the agency would not reflect the rule changes in individual permits until they expired and were reissued at the end of their terms.

This approach would avoid duplication or inconsistency in the factual or analytical portions of individual proceedings. It would not, however, deal with the more difficult policy problem raised if any one of several sources could be controlled to attain a given ambient level, and the agency had to choose among these different control patterns. Two solutions to this problem are possible. First, and simplest, any conflicts could be directly addressed in a generic decision, either at the rulemaking stage if they surfaced there, or else in a permit proceeding to which all potentially affected sources were parties. This type of permit proceeding would be similar to a "comparative" hearing to award a TV or radio license or an airline route.

A comparative hearing approach, however, would seldom be the best solution. Comparative proceedings represent an effort to confront the complexities of a decision head on, without the preliminary use of simplifying assumptions. That effort has historically proved unwieldly and inefficient. ${ }^{134}$ These characteristics would probably persist even if adjudicatory hearings were not

132 The classic statement is $H$. Frimendly, The Federal Adnomistrative Agencies: The NeEd for Better Definttion of Standards (1962).

133 See note 123 supra \& accompanying text.

134 See S. Brexer \& R. Stewart, Administrative Law and Regulatory Policy 373, 572 (1979); H. FrIENDLY, supra note 132, at 55-56, 70-73 (FCC), 91, 97-98 (CAB); Senate CoMmitee on the Judiciary, StafF of Subcomimttree on admmistrative Practices and Procedures, Report on CAB Practices and Procedures, 94th Cong., Ist Sess. (1975); Anthony, Towards Simplicity and Rationality in Comparative Broadcast Licensing Proceedings, 24 StaN. L. Rev. 1, $3-5,39,47-55,109-10$ (1971). 
used.135 Furthermore, the nature of the problem of air pollution control neither allows nor demands the absolute precision that comparative hearings might appear to offer. Given the technical uncertainties that becloud the area, the actual ambient effect of any given emissions allocation is bound to be subject to a substantial margin of error. In addition, the potential harms caused by air pollution appear to vary smoothly rather than discontinuously with exposure levels. ${ }^{136}$ That in turn suggests that the costs of small mistakes in allocating emissions among sources would also be small.

All of these difficulties of a permits system based on comparative hearings could be alleviated by a second type of approach which would rely on broad rules of decision for allocating controls among several eligible sources. The most economically efficient variation of this approach would be to determine the total amount of emissions that could be tolerated, and then auction an equal number of emission "rights" off to the highest bidders. ${ }^{137}$ If that is not acceptable, a simple rule stating that no less (and, perhaps, no more) of the necessary reductions could be assigned to any one source would be sufficient. That rule would link together individual proceedings; more particularly, it would contain the most troublesome potential problem raised by issuing linked permits over time. The danger is that an agency might largely exempt from controls the first sources to receive permits by asserting that later sources would be tightly regulated, and then renege when the time arrived to issue those later permits. Although this test would be a rough one, any resulting inefficiencies could be reduced by allowing the sources to later trade the allowable emissions among themselves, as described earlier. The important point, no matter which of these variations is adopted, is that a framework of broad rules should be

135 Commentators have often identified as a major problem the use of trial-type hearings for making permit decisions that rest on policy choices or the assessment of complex facts and that do not involve judgments of wrongdoing. See STAFF of Senate Commttee on Governamental Affatrs, Study on Federal Regulation; Delay in the Regulatory Process, S. Doc. No. 72, 95th Cong., 1st Sess. (1978). Less formal types of procedures have been developed that can handle these questions and still be fair to all concerned. Pedersen, The Decline of Separation of Functions in Regulatory Agencies, 64 VA. L. REv. 991 (1978). Avoiding trial-typo hearings, however, would not address the need to pull individual decisions into a coherent scheme. See H. FriendLY, supra note 132, at 174, remarking:

Of the scores of administrative adjudications we have considered, I do not recall one that has raised an issue as to ... any of the ... important adjective rights that are the staples of the usual administrative law course. All the formalities have been faithfully pursued-the book has been duly lissed; the trouble has been with the product.

136 H. LANDSBERG, supra note 12, at $361,364,368,375$.

137 See text preceding note 23 supra. 
formulated to guide and link together individual permit proceedings.

\section{b. A Permit System and New Knowledge}

Establishing a set of general rules to guide individual permit decisions would narrow the differences between a permit system and the present statute's structure. Certain rules-those that established the air quality baseline, the inventory, the model, and the permitting strategies-would mirror much of what SIPs now contain. Other general rules, as at present, might take the form of national regulations. ${ }^{138}$ Despite these similarities, the immediate mechanical virtues of a shift to permits would be preserved to the extent that permits alone contained federally enforceable regulatory provisions that actually bound individual sources, with general rules simply providing the backdrop.

More fundamentally, a statute that combined general rules for issuing permits with individual permits containing control requirements would handle new knowledge better than the present statute, both on a day-to-day level and in overall design. On the day-to-day level, the system's distinctive feature would be that the general rules for issuing permits could change at any time, while the individual permits themselves would seldom change before they expired and were reissued at the end of their terms.

The present Act provides no means of scheduling changes in a SIP, and forces any changes to take effect in time to meet the short statutory deadlines. ${ }^{139}$ The result has been a resistance to new knowledge because of the disruption and uncertainty that such knowledge generates. By providing a fixed period, during which permits would generally not change, and a predictable time at which they would be reexamined, a permit system would be "buffered" against the effects of new knowledge. That knowledge would enter the system only at definite times and in definite proceedings. ${ }^{140}$ Moreover, at the specified times for considering permit

138 See note 36 supra.

139 See notes 43 \& 51 supra and text accompanying note 70 supra.

140 Moreover, an agency's use of a permits system to affirmatively encourage new knowledge could go beyond the basic and largely automatic effects detailed above. If the agency were to leave certain questions open for resolution in individual permit proceedings, those proceedings would then develop information useful for updating the general rule. The burden of proof could be appropriately shifted in such cases to reduce the chances that individual decisions would disrupt the overall scheme.

According to Judge Leventhal, "[o]n the issue of burden of proof, the standard adopted must take into account the nature and consequences of the risk of error." International Harvester Co. v. Ruckleshaus, 478 F.2d 615, 642 (D.C. Cir. 1973). 
changes, the elimination of the double key would make them easier to accomplish.

These characteristics of a permit system reflect its more fundamental virtue: it corresponds more closely to our understanding of the kind of problem that air pollution is than does the existing system. The present SIP system is based on a short-term effort to achieve standards. It assumes that we know what is necessary, that what remains is to act, and that the need to act is urgent. This is the implicit message behind the directive that all SIPs be submitted at one time, that all necessary calculations and modelling be made then, that these calculations and modelling be speedily approved or disapproved, and speedily corrected where necessary, and that compliance follow promptly. It is also the implicit message behind the complete lack of any mechanism for handling change in an orderly manner.

This approach is, of course, not even intellectually appropriate where the air is already clean and regulation seeks to preserve its quality. Nor does it fit areas where efforts to attain standards have been successful, and keeping the air clean has become the issue. Even where the standards have not been met, the constant development of new knowledge casts considerable doubt on both the merits and workability of this system.

A permit approach would impose a different philosophy on the system. The universe of permits could be set to expire and be renewed at a relatively constant rate. Any necessary changes could be introduced into the regulatory system permit by permit over an entire renewal cycle, rather than being imposed simultaneously upon all sources, as is at least theoretically the case under the SIP system. As a necessary consequence, the artificial deadlines in the current law would be deemphasized in favor of a continual, gradual nudging of the regulatory system toward better results over time. ${ }^{141}$

The permit-based approach, by allowing different permits with different expiration dates to contain somewhat different provisions, accepts and makes manageable the inability to do everything at once that is inherent in any complex regulatory scheme. It is the natural

Similarly, the somewhat conflicting aims of running a uniform and efficient regulatory scheme and developing useful new information in case-by-case proceedings could be roughly reconciled by allowing individual case exemptions from a general rule, but only by meeting a significant burden of proof. See Environmental Defense Fund, Inc. v. EPA, 548 F.2d 998, $1013-15$ (D.C. Cir. 1976) (Leventhal, J., supplemental opinion), cert. denied, 431 U.S. 925 (1977); Leventhal, Environmental Decisionmaking and the Role of the Courts, 122 U. PA. L. REv. 509, 535-36 (1974).

141 The National Commission on Air Quality has recommended not just deemphasizing, but eliminating, the present mandatory attainment deadlines. NAT'L CoMmission, supra note 12 , at $2.2-10$. 
procedural vehicle by which to shift the Act from an emphasis on short-run acute effects to an effort of long-term maintenance and gradual improvement.

\section{Permits and Economic Efficiency}

A permits approach is tightly linked to efforts to create a more economically efficient pollution control system. As we have seen, "trading" pollution reductions among sources in effect requires the type of source-specific, enforceable emission controls that a permit, or its functional equivalent, provides. ${ }^{142}$ Absent such controls a market system would likely prove unenforceable. In addition, the increased stability and predictability accompanying regulatory requirements in a fixed-term system would encourage trading. The fixed permit term would allow sources to invest in creating emission reductions, or to purchase them, with greater assurance than at present that regulatory changes would not diminish the value of that asset.

The frequent amendments to source-specific control requirements that would accompany a "pollution rights" system might initially seem difficult to reconcile with the stability and certainty that a permit system is designed to provide. There is a sharp distinction, however, between this type of regulatory change and the type of change frequently mandated under the present law. Changes associated with "pollution rights" are made at the request of the regulated source to meet existing requirements in a more efficient way. These should be freely allowed. On the other hand, changes based on new knowledge or on new policy choices generally signal a regulatory change of course. These should generally be made only when permits expire. By treating different types of regulatory changes differently, a permit system could efficiently process trading while avoiding the evils of uncertainty and unpredictability.

\section{Realizing the Full Benefits of a Market System}

The Clean Air Act, as presently administered, imposes one substantial obstacle to broad reliance on a market system. For several important pollutants, ${ }^{143}$ the current regulatory approach

142 See text following note 73 supra.

143 The most elaborate modelling requirements concern sulfur oxide and particulates. See 45 Fed. Reg. $77,459,77,461$ nn.6 \& 7 (1980) (stating the EPA policy of requiring detailed site-specific modelling to determine the proper control levels for sulfur oxide and particulates, but not requiring detailed modelling for photochemical oxidants). See also Cleveland Elec. Illuminating Co. v. EPA, 572 
relies heavily on detailed modelling and monitoring, not just of emissions in a region, but of the local impact of individual sources. The result can be to establish a fairly rigid system of source-specific emissions limitations, one that demands controls on a given source regardless of relative cost, because only controls on that source will be assured of removing measured or projected violations in a particular local area. ${ }^{144}$

To the extent that the scientific and engineering design of the system itself thus precisely specifies the emission limits for each individual source, the efficiency benefits of reallocating those limits through the market become unattainable. Such a sacrifice of efficiency might be justified if detailed source-by-source modelling had unique advantages in preventing the harms that the Act seeks to control. Experience so far, however, seems to cast doubt on any such advantages.

Detailed modelling and monitoring of individual pollution sources has been difficult and expensive to apply in practice. ${ }^{145}$ The results obtained inevitably contain a substantial margin of uncertainty, and there is usually room for considerable doubt whether the health or welfare differences between two readings in roughly the same area are in fact significant. As a result, questions have been raised as to whether, even under the current control scheme, the statute may not unduly rely on modelling and monitoring.

The doubts about modelling multiply where measures to reduce the long-range impact of air pollution are at issue. It is presently impossible to accurately model areas beyond the size of a small city, even when only physical dispersion is at issue. Furthermore, many of the long-range effects of pollution are thought to result from the chemical transformation over time of pollutants in the atmosphere, thus introducing more complexity into modelling efforts. Finally, since both the causes and effects of long-range pollution cover wide regions and act on a large scale, detailed modelling of individual sources may always be of limited value in understanding or dealing with the problem. ${ }^{146}$

F.2d 1150 (6th Cir. 1978); Modelting Gumbunnes, supra note 14, at 18-24 (recommending four classes of models for sulfur oxides and particulates, one each for carbon monoxide and nitrogen dioxide, and none for photochemical oxidants).

144 If the model is complex and site-specific, sources will not be able to determine in advance whether their trades will be acceptable under the regulatory scheme. Any complex model involves room for disagreement and for the possibility that the regulatory agency simply may not accept the source's conclusions. This is much less likely where a simple mathematical reallocation of emissions is concerned.

145 See Nat'L Commission, supra note 12, at 3.5-36-37.

${ }^{146}$ See H. LANSBERG, supra note 12 , at $340,343,403-04$. It should still be possible, however, to use "regional" models to describe the causes and distribution 
These considerations suggest that an approach that looks more toward general reduction of pollutants that have long-range effects within a broad area is likely to be at least as effective as a system that relies on detailed assessment of individual sources. A regulation adopted under such an approach might state, for example, that "By the year 19-, sulfur oxides emissions in the $\mathrm{X}$ region shall not exceed Y million tons." 147 This type of general ambient approach could be readily adapted to a market-based regulatory system. At the outset, the control agency under such a system would have to allocate the allowed regional emissions among sources. ${ }^{148}$ Subsequently, the system would have to provide some mechanism for transferring these "allowable emissions" among sources as sources expanded or closed down, or switched fuels, or improved their controls. The policy arguments for doing this through an "emission rights" approach under a permits system are even stronger than those for using such an approach under our current system. A scheme of general pollution reduction would almost certainly cover a far larger area and include more sources than current SIPs do. Increasing the number of sources covered would increase the potential for efficiency gains through a market approach by increasing the number of participants in that market.

At the same time, the switch to a policy concerned with total emissions, rather than site-specific impacts, would remove much of the need for detailed examination of individual transactions. The regulatory agency would only have to be satisfied that total emissions of all regulated sources would stay below the limits, and it would not focus on the exact impacts at each particular source. This limiting of the review standards would widen the class of permissible trades and would make it easier to determine in advance which trades qualified. That in turn would increase the potential for efficiency gains through trading while smoothing the mechanical workings of the statute.

even of these pollutants. These models would cover a broader area, and their inputs and outputs would be more aggregated than is the case for a source-bysource model. See NAT'L Comarission, supta note 12, at 3.9-15-17.

147 This approach would not compel abandoning the ambient foundations of the statute. First, the required reductions should not be set by Congress, but by the control agency in a general rulemaking proceeding based on analysis of the environmental effects of the pollutants involved. Second, the rule could be given a more elaborate form where necessary to deal with more refined issues. For example, the rule might only cover "plumes" of emissions that rose to a certain height and thus became subject to broad dispersion. Regional models such as those discussed in the previous note could be used to help derive such conditions.

148 The most economically efficient way to do this would be an auction. See text above note 23 supra. 


\section{Coordination with States and with Other EPA Statutes}

\section{a. Coordination with States}

By far the most substantial contribution that a permit system would bring to state-federal relations would be the elimination of the double key. ${ }^{149}$ Beyond that, there is some reason to hope that a permit-based system would remove some of the legal complexities that attend the present statute.

The building blocks of the proposed system-the permitswould, procedurally, either be entirely state or entirely federal. Accordingly, the status of a state-issued permit in litigation would be easy to determine. If the state courts overturned it, federal law would provide no grounds for denying effect to that decision. That is not the case under the existing SIP framework. ${ }^{150}$ Accordingly, by this change the EPA would concede a line of defense that is at present the subject of at least some dispute. For several reasons, however, this change probably would not make the control system as a whole more vulnerable to legal challenge or to other changes in state law.

Most obviously, the present system essentially produces confusion, rather than a genuine deterrent to state law changes. In addition, under the proposed approach challenges to permits would proceed case by case. The overturning of controls in one case would affect only the emitter challenging the permit conditions in that case. The legal action would not affect other plants, even in similar circumstances, that might have accepted their permits. ${ }^{151}$ A system that produced remands limited to single sources would allow the state to respond quickly, at least to some of them, or

149 See notes 64-70 supra \& accompanying text.

150 See text above note 81 supra.

151 The EPA has adopted this approach under the Clean Water Act, successfully arguing that certain questions arising under rules for calculating permit conditions were not ripe for judicial review until they were applied in individual permit proceedings. Diamond Shamrock Corp. v. EPA, 580 F.2d 670 (D.C. Cir. 1978). Cf. American Iron \& Steel Inst. v. EPA, 543 F.2d 521, 528 (3d Cir. 1976) (decision on jurisdictional grounds, but dicta suggest ripeness considerations).

Similarly, some courts deciding Clean Air Act cases have cited the possibility of general disruption in refusing to pass on technical issues specific to one source when reviewing EPA approval of a complete state SIP, and have suggested that such claims should instead be heard in the source-specific context of an enforcement proceeding. Indiana \& Mich. Elec. Co. v. EPA, 509 F.2d 839, 845 (7th Cir. 1975). In two other cases, the court, in remanding an EPA action, confined the relief granted to the specific sources petitioning, even though the issue raised and decided was generally applicable. Sharon Steel Corp. v. EPA, 597 F.2d 377, 381 (3d Cir. 1979); Duquesne Light Co. v. EPA, 481 F.2d 1, 10 (3d Cir. 1973). Cf. Cleveland Elec. Illuminating Co. v. EPA, 572 F.2d 1150, 1162-63 (6th Cir. 1978) (citing the small percentage of affected sources challenging a rule as a reason for upholding it). 
would allow the EPA to issue a superseding permit if it did not. The present generic approach, by contrast, can leave all affected sources uncontrolled for years while the remand continues. Building the regulatory system around control requirements fixed for a permit term would discourage efforts by polluters to get administrative or legislative relief during that term. Under the SIP approach, as we have seen, ${ }^{152}$ that relief is potentially available at any time.

None of these aspects of a permits system would change the status of generic rules for issuing permits. If affirmative EPA approval were required there, questions similar to those we face at present could persist. Once again, however, the fixed term would shield individual permits until they expired. That would cushion the impact of rule changes on the regulatory system. Furthermore, these general rules would contain very few control requirements; rather, they would contain data, analytical approaches, and strategies. That lack of immediate bite might well reduce the profitability, and perhaps the probability, of legal challenge.

Under a permit-based system, a state could make regulatory decisions at one of two stages: in making the general rule for issuing permits, or in issuing the permits themselves. That would provide two additional ways to cushion the system from legal challenge.

First, thorny questions that concerned only one or a few sources could be dropped from the general rule and addressed in individual permit proceedings. Once isolated there, no decision about them would affect either the general rule or the other permits. Often this reduction in risk might be well worth the efficiency loss resulting from the shift from generic to case-by-case decisions. ${ }^{153}$

Second, the statute could provide some means for making decisions on individual permits in a "second-best" way, even if the general rule for issuing those permits had been overturned. For example, if an area could not establish an ambient rule for issuing permits, it might be empowered to issue permits based either on technology-based standards or on some set standard for cutting back emission levels. A similar approach, though under a less

152 See notes 58-63 supra \& accompanying text.

153 The EPA has successfully asserted a right to set control standards for individual dischargers on a case-by-case basis in individual Clean Water Act permit proceedings where the generic rules for determining those controls have not yet been issued or where the rules have been judicially disapproved. See Clean Water Act $\$ 402(\mathrm{a})(1), 33$ U.S.C. $\$ 1342(\mathrm{a})(1)$ (1976); United States Steel Corp. v. Train, 556 F.2d 822, 844 (7th Cir. 1977). 
demanding statutory framework, has worked well under the Clean Water Act. ${ }^{154}$ Such a safety net, at a minimum, could protect against the unconsidered loosening of controls. That in turn, by reducing the likelihood that future pollution levels would exceed current ones, would support the broader decision to shift the Clean Air Act to a generally more gradual approach.

\section{b. Consistency with Other EPA Statutes}

Each of the other major EPA pollution control statutes rests on fixed-term permits, issued and reissued by states at fixed intervals and subject to EPA veto within a definite short time. On a procedural level, then, coordination with these other statutes calls for making the Glean Air Act a permitting statute also. The different laws could be coordinated in practice by the simple expedient of issuing and reissuing the permits simultaneously..$^{165}$

This would be more than a bureaucratic convenience. Such coordinated issuing of permits could provide a forum for discovering conflicting EPA requirements and setting priorities among control tasks. If the air pollution and water pollution requirements were inconsistent, a consolidated permit hearing would be the place to find out. If a great deal more air pollution control could be obtained by easing up a little bit on water pollution control (or vice versa), a consolidated proceeding could allow the regulatory

154 The Clean Water Act's permit requirements are discussed at text accompanying notes 115-24 supra. In other environmental contexts, the Resource Conservation and Recovery Act (RCRA) requires each facility for the "treatment, storage or disposal of hazardous waste" to obtain a permit from the EPA or an approved state, 42 U.S.C. $\$ \$ 6925,6926$ (1976); the Safe Drinking Water Act requires regulation, by rule or permit, of any underground injection of a "fluid," 42 U.S.C. $\$ \oint 1421(\mathrm{~b})(1)(\mathrm{B}),(\mathrm{d})(1)$ (Supp. III 1979), and the Ocean Dumping Act prohibits any dumping of material into ocean waters without a permit from the EPA (or, in some circumstances, the Corps of Engineers), 33 U.S.C. \$\$ I4021405 (1976). In addition, the Corps of Engineers' program for regulating dredged or fill materials also operates by permit. The EPA has substantial authority over the decisions made in this program, and in the future the program will be increasingly taken over by approved states, subject to EPA review, just like the Clean Water Act or RCRA programs. 33 U.S.C. \$1344 (Supp. III 1979).

The EPA has issued detailed Consolidated Permit Regulations, meshing to a large degree the regulatory requirements through which the Clean Water Act, RCRA, underground injection control, and " 404 " permit programs will be operated in practice. See note 114 supra.

155 The EPA's Consolidated Permit Regulations allow this for the permits that they cover. See 45 Fed. Reg. 33,377, 33,407 (1980); 40 C.F.R. \$122.9(e) (1980). Whenever permits are being issued at roughly the same time, either because the applicant is a new source and must obtain its permits all at once, or because the previous permits were set to expire together, the Consolidated Permit Regulations allow (but do not require) common regulatory proceedings to be held in connection with the issuance or reissuance of all those permits. See 40 C.F.R. $\S 124.4$ (1980). 
agencies to discover that and act accordingly. In short, the process of laying out these different factors, and balancing them against each other, would contribute in a small way to a general shift in perspective for environmental regulation similar to the one I advocate for the Glean Air Act.

\section{CoNClusion}

Any national air pollution control effort will necessarily be complicated, and in at least some ways it must grow more complicated over time. The complexities of the SIP approach under the Glean Air Act, however, are based on a misunderstanding of the problem, and should be replaced. They hamper the introduction of new knowledge into the system, discourage economic efficiency, and lead to conflict both between states and the EPA and between the Clean Air Act and other EPA statutes.

Fixed-term permits, by contrast, would "buffer" the incorporation of new knowledge, and so encourage it, would provide a vehicle suited to implement a market-based approach, and should work smoothly both across the state-federal boundary and with other EPA statutes. In short, if the Glean Air Act is to authorize a regulatory program that can change smoothly, slowly, and continuously over time as new knowledge arises, rather than one that requires a series of sudden efforts, the use of permits is the ideal approach. 